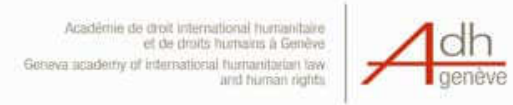

Ownership of Norms Project - Toward a better protection of civilians in armed conflicts Draft for comment, February 2010

\title{
The Rights and Responsibilities of Armed Non-State Actors: The Legal Landscape \& Issues Surrounding Engagement
}

\author{
Andrew Clapham \\ Geneva Academy of International Humanitarian Law and Human Rights
}




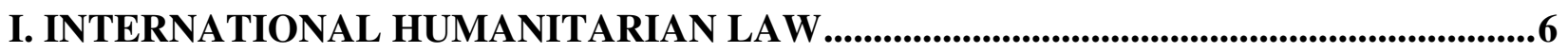

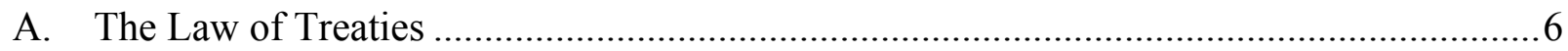

B. Contemporary Customary International Law.................................................................... 10

C. Rebellion, sedition, insurrection, civil war, and belligerency .............................................16

D. Special Agreements, Unilateral Declarations, and Codes of Conduct ...............................19

E. When will an armed non-state actor be the bearer of these international obligations?......20

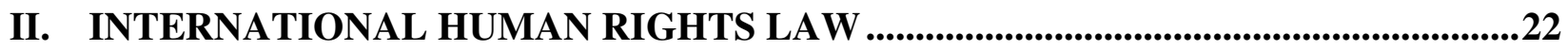

A. UN Special Mechanisms on Human Rights and Non-State Armed Groups ......................27

B. UN Human Rights Field Officers..................................................................................

C. The Work of the Security Council and the Special Representative on Children in Armed Conflict................................................................................................................ 31

D. Non-Governmental Approaches and the Example of Geneva Call.....................................32

III. INTERNATIONAL CRIMINAL LAW .................................................................................34

A. International Crimes and Superior Responsibility by Responsible Commanders from

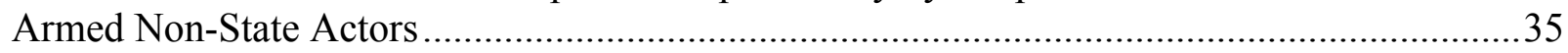

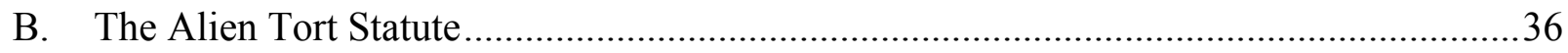

IV. IS ENGAGEMENT WITH NON-STATE ACTORS A VIOLATION OF THE NONINTERFERENCE RULE IN INTERNATIONAL LAW?....................................................39

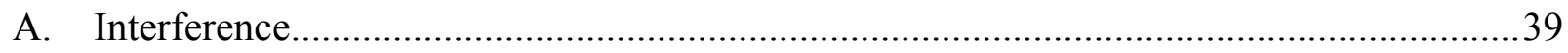

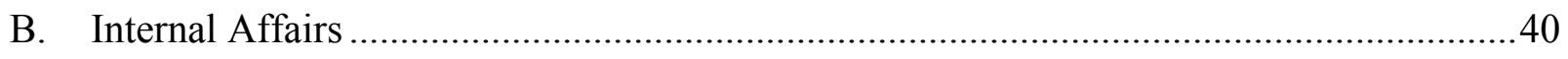

C. Who has the Obligation not to Interfere? ....................................................................4

V. NEW DIRECTIONS FOR ENGAGEMENT AND OWNERSHIP..............................41

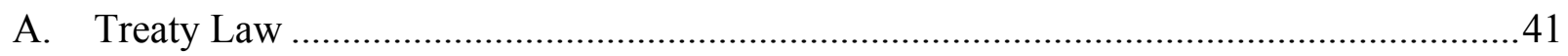

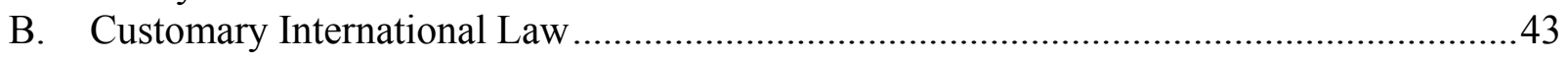

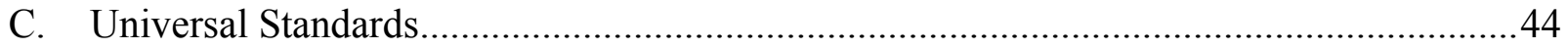




\section{INTRODUCTION}

This paper is designed to stimulate discussion in the context of the project on the 'Ownership of Humanitarian Norms by Armed Non-State Actors'. It attempts to outline the legal landscape regarding the international responsibilities of armed non-state actors and addresses issues surrounding engagement with such groups. Much has been written on the need to engage nonstate armed groups over humanitarian norms, ${ }^{1}$ and manuals have been written on how best to go about this, ${ }^{2}$ but hardly any attention has been given to the existing legal landscape. ${ }^{3}$ This is understandable at one level. International law is usually seen as part of the problem rather than part of the solution. It is clear that the exclusion of armed groups from the normal treaty-making process and their subsequent inability to become parties to the relevant treaties means that alternative regimes have had to be adopted. At a more abstract level the doctrinal notion that the international legal system has a limited number of 'subjects' and that these are primarily states, or the entities that states create, has meant that, not only is international law seen as unpromising, but international law is also seen as inimical or even hostile to the aims of the armed groups at issue: 'A legal system which treats actors as second-rank citizens should not be surprised that those second-class citizens aim to upgrade their status, and the shortest route to being heard and being taken seriously is through violence'. ${ }^{4}$

This paper considers that the traditional approach, which sees international law as excluding armed non-state actors from its list of suitable subjects, is not only unhelpful, but also dangerous. Moreover it will be argued that the time has come for a radical rethinking of these issues as the international legal system itself has undergone major upheavals since the traditional approach first took hold. Most importantly, we have to admit that international law is now concerned with individuals, and that these individuals have international rights and obligations.

\footnotetext{
${ }^{1}$ See e.g. Program on Humanitarian Policy and Conflict Research Harvard University and Graduate Institute of International Studies Geneva, Empowered Groups, Tested Laws, and Policy Options, (2007).

${ }^{2}$ See G. McHugh and M. Bessler, Humanitarian Negotiations with Armed Groups: A Manuel for Practitioners (New York: United Nations, 2006); Conciliation Resources, Choosing to engage: armed groups and peace processes, (London: Accord, 2009); M.P. Glaser, Humanitarian engagement with non-state armed actors: The parameters of negotiated access, (London: Humanitarian Practice Network, ODI, 2005). For case studies see the series produced by the Centre for Humanitarian Dialogue Humanitarian engagement with armed groups: 'The Central Asian Islamic opposition movements' (2003); 'the Colombian paramilitaries' (2002); and see the Opinion by A. Potter 'Women and negotiations with armed groups' (2008).

${ }^{3}$ For some discussion on the perceived gaps in the legal regime see the report by the Program on Humanitarian Policy and Conflict Research at Harvard University (HPCR), Transnationality, War and the Law: A Report on a Roundtable on the Transformation of Warfare, International Law, and the Role of Transnational Armed Groups, (Harvard: HPCR, 2006); for an excellent discussion of the legal issues see M. Sassòli, 'Transnational Armed Groups and International Humanitarian Law', (Harvard University: Program on Humanitarian Policy and Conflict Research, 2006).

${ }^{4}$ J. Klabbers, '(I Can't Get No) Recognition: Subjects Doctrine and the Emergence of Non-State Actors', in J. Petman and J. Klabbers, (eds), Nordic Cosmopolitanism. Essays in International law for Martti Koskenniemi, (Leiden: Nijhoff, 2003) 351-69 (reproduced in A. Bianchi, (ed), Non-State Actors and International Law, (Dartmouth: Ashgate, 2009) 37-55, at 54-5. The International Law Commission has suggested that successful insurgents carry over their internationally wrongful acts so that they are then seen as the responsibility of the new state or government, see A. Clapham, 'Human rights obligations of non-state actors in conflict situations', vol. 88 International Review of the Red Cross 863, (2006) 491-523, at 508-9; this approach has been challenged on the grounds that there is no legal evidence for such a rule and that in policy terms it makes sense to exclude such attribution to the state where 'a national reconciliation or power sharing agreement leads to democratic elections which eventually bring the rebels to power.' J. D'Aspremont, 'Rebellion and State Responsibility: Wrongdoing by Democratically Elected Insurgents', vol. 58 ICLQ (2009) 427-42, at 437.
} 
Let us therefore start from a new perspective: that of the individual. The individuals that compose these armed groups have rights and responsibilities under international law. ${ }^{5}$ It is now uncontroversial that every individual is entitled to a catalogue of international rights under customary international law; ${ }^{6}$ these rights are complemented by the rights enjoyed under certain treaties where the state party to the treaty is responsible for its acts or omissions towards that individual. It is also uncontroversial that every individual in the world has certain international obligations not to commit international crimes such as genocide, crimes against humanity or war crimes. These obligations are not dependent on whether or not the individual acts through a state or non-state actor. In both situations the individual has violated international law, and in some cases there will be a court with jurisdiction ready and willing to prosecute such acts as violations of international law. The question of the individual's consent is seen as irrelevant. Individuals are bound by this customary international law, whether or not their state or their non-state armed group consented to be bound by the rule.

The extent to which an organization or group can enjoy these international human rights remains an unexplored area in practice and in the doctrine. The law and practice of the European Court of Human Rights make it clear that non-governmental organizations can seize the Court and complain as victims of human rights violations. Human rights organizations, trades unions, political parties, and corporations have all been successful applicants before the Court. Of course not all rights can be simply transposed onto the non-state actor. A number of early applications ruled out the idea that non-physical entities have a right to freedom of conscience, although churches and religious organizations have a right to manifest religion, ${ }^{7}$ and a religious foundation was held unable to claim the right to education. ${ }^{8}$ Non-state actors have no right to marry (no fundamental right to merger!). Nor can non-human non-state actors complain of torture or

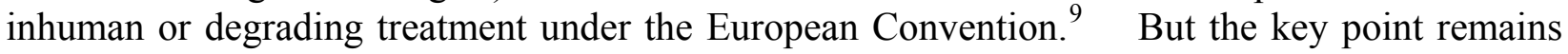
that organizations are capable of bearing some international rights and that this has been accepted with regard to a limited number of human rights more generally. ${ }^{10}$ For a reminder of a situation which arose outside the context of an application to the European Court of Human Rights we might recall the two year international arbitration between Greenpeace and France after the sinking of the Rainbow Warrior the three person Geneva-based international arbitral tribunal determined that $\$ 8.159$ million should be paid by France to Greenpeace (this included $\$ 1.5 \mathrm{~m}$ punitive damages).

\footnotetext{
${ }^{5}$ See e.g. Y. Dinstein, The Interaction Between Customary International Law and Treaties, vol. 322 RCADI (The Hague: Brill, 2006) 243-427; 'Since the dawn of international law, obligations have been imposed directly on individual human beings through customary prohibitions of certain modes of conduct... Only in more recent times has customary international law conferred rights straightly on human beings.' At 338.

${ }^{6}$ According to Dinstein 'But it is impossible to deny today that the core of the Universal Declaration of Human Rights has come to reflect customary international law.' Supra at 338.

${ }^{7}$ See eg Kustannus Oy Vapaa Ajattelija AB (Publishing Company Freethinker Ltd. et al v Finland, Applic. 20471/92, 15 April 1996; Verein 'Kontakt-Information-Therapie (KIT) and Siegfried Hagen v Austria, 11921/86, 12 October 1988; Xv Switzerland, 27 February 1979.

${ }^{8}$ Ingrid Jordebo Foundation of Christian Schools and Ingrid Jordebo v Sweden, 6 March 1987.

${ }^{9}$ KIT v Austria (Supra).

${ }^{10}$ For some comparative constitutional law examples of human rights claims brought by non-physical persons see M.K. Addo, 'The Corporation as a Victim of Human Rights Violations', in M.K. Addo (ed), Human Rights Standards and the Responsibility of Transantional Corporations, The Hague: Kluwer Law International (1999) 187-96; see also M. Emberland, The Human Rights of Companies: Exploring the Structure of ECHR Protection, Oxford: Oxford University Press (2006)
} 
The scope of international obligations which attach to non-state organizations is similarly underdeveloped in law and practice. All relevant existing international courts only allow for cases to be brought against states or individuals. One should not, however, draw the conclusion that the absence of international jurisdictions means that non-state armed groups have no obligations under international law. First, the historic practice of recognizing such groups as belligerents or insurgents was nothing less that an explicit acceptance by the relevant states that the armed nonstate actor had international rights and obligations that were to be respected. Second, Common Article 3 to the Geneva Conventions of 1949 sets out provisions which 'each Party to the conflict' is bound to apply; and this has usually been interpreted to confirm that armed non-state groups have a set of international obligations. Third, the Security Council has increasingly called on armed non-state groups to respect international law. Fourth, national courts have had occasion to consider the international obligations of armed groups when determining whether a Government supplying arms to that armed non-state actor was assisting in a violation of the international law. ${ }^{11}$

In order to develop this last section on the obligations of non-state armed groups it will be helpful to break this topic down into the following chapters: international humanitarian law, international human rights law, and international criminal law. Of course this breakdown is problematic in that a single act might fall within all three categories, and there will be different points of view on where an issue should most properly be dealt with. But the aim here is not to resolve all the tensions and overlaps between these three branches of law, rather the goal is to address the lawyers and practitioners who work in these three branches; here the division makes more sense as it is a fact that for each branch the international treaty law-making process takes place in separate arenas with separate constituencies. Although some individuals may participate in all three arenas, this is the exception rather than the rule, and so we will consider these branches separately. In this way we might provide a picture of the legal landscape which is recognizable to the players that inhabit each field and provide ways of seeing for those who see the other fields as alien territory.

Lastly, we will examine a separate question of international law. Is third party engagement with an armed non-state actor a violation of the rule in international law which forbids interference in internal affairs?

${ }^{11}$ Dealt with in Section III.B below. 


\section{INTERNATIONAL HUMANITARIAN LAW}

In 2004, the Appeals Chamber of the Sierra Leone Special Court simply held that 'it is well settled that all parties to an armed conflict, whether states or non-state actors, are bound by international humanitarian law, even though only states may become parties to international treaties'. ${ }^{12}$ It has now become uncontroversial, even commonplace, ${ }^{13}$ to refer to non-state parties to an armed conflict being bound by international humanitarian law - the legal reasoning required to come to this 'well settled' conclusion remains, however, unclear. Does this matter? If groups are anyway clearly bound is it not then the height of self-indulgence to open an inquiry as to why they are bound? We suggest not; by asking ourselves why groups should be considered bound we may expose the strengths and weaknesses of certain arguments, ${ }^{14}$ and see which legal route represents the best chance of success with regard to engaging armed groups and enhancing the ownership of humanitarian norms.

\section{A. The Law of Treaties}

Common Article 3 to the Geneva Conventions of 1949 is addressed to 'each Party to the conflict' and this Article applies to conflicts 'not of an international character'. The treaties then would seem to have a provision which directly binds the non-state armed group. The problem arises, however, in the following way: treaties are only binding on the contracting parties to them, and the Geneva Conventions and related humanitarian law treaties are not normally open for signature by armed non-state groups. The exception to this general rule is where a third state accepts to be bound by the treaty obligations in question. ${ }^{15}$ And an exception in the particular field of international humanitarian law can be found in Article 96(3) of the 1977 Additional Protocol I to the Geneva Convention of 1949 allowing for a declaration by certain armed nonstate actors (known as national liberation movements) that such an actor undertakes to apply the Protocol and the Geneva Conventions to that particular conflict. ${ }^{16}$

\footnotetext{
${ }^{12}$ Prosecutor v. Sam Hinga Norman (Case No. SCSL-2004-14-AR72(E)) Decision on Preliminary Motion Based on Lack of Jurisdiction (Child Recruitment), Decision of 31 May 2004, at para. 22.

${ }^{13}$ Consider the Updated European Union Guidelines on promoting compliance with international humanitarian law (IHL) (2009/C 303/06) 15 December 2009, 'States are obliged to comply with the rules of IHL to which they are bound by treaty or which form part of customary international law. They may also apply to non-State actors. Such compliance is a matter of international concern.' At para. 5. Note the source of obligation for non-state actors is not specified. Compare the Swiss Federal Department of Foreign Affairs 'Non-state actors - including armed groups - are playing an ever greater role today in armed conflicts. Although they are not parties to international law treaties, non-state actors are obliged to respect the rules of customary international law. It follows that international humanitarian law is also legally binding on non-state actors.' ABC of International Humanitarian Law at p. 32 .

${ }^{14}$ For analyses of this question see Sivakumaran Sandesh, 'Binding Armed Opposition Groups', vol. 55 International and Comparative Law Quarterly (2006) 369-94; M. Sassòli, 'Transnational Armed Groups and International Humanitarian Law', (Harvard University: Program on Humanitarian Policy and Conflict Research, 2006) esp. at 14; K. Nowrot, 'International Legal Personality of Influential Non-State Actors: Towards A Rebuttable Presumption of Normative Responsibilities', vol. 80 Philippines Law Journal (2006) 563-86 at 580-586; L. Zegveld, Accountability of Armed Opposition Groups in International Law, (Cambridge: Cambridge University Press, 2002); A. Cassese, 'The Status of Rebels under the 1977 Geneva Protocol on Non-International Armed Conflicts', vol. 30 ICLQ (1981) 416-39.

${ }^{15}$ See now Article 34 of the Vienna Convention on the Law of Treaties (1969).

${ }^{16}$ No such Declaration has ever entered into force. Note for the purposes of this provision the non-state actor would have to be an 'authority' representing a people 'fighting against colonial domination and alien occupation and against racist régimes in the exercise of their right of self-determination, as enshrined in the Charter of the United Nations and the Declaration on Principles of
} 
The principle that third states cannot be bound by a treaty to which they are not a party is so familiar, and so obviously derived from principles of contract law, that it is often associated with the Latin maxim: pacta tertiis nec nocent nec prosunt. In the face of this formidable Latin obstacle should we not simply conclude that in the face of a principle dating back to Roman Law there is nothing a treaty can do to bind an armed group? Perhaps not, perhaps we should look a little more closely at the changing structure of the international legal system. First, it is increasingly accepted that a treaty can create not only rights for individuals but also obligations. Dinstein puts it bluntly: 'It is a commonplace today that treaties can directly impose obligations on - and accord rights to - individual human beings. ${ }^{17}$ We can ask why these third parties can be bound and yet conventional doctrine would suggest that a collection of such individuals is not so bound as a group? ${ }^{18}$

Second, the UN Charter is a treaty, and, as such, one might assume that it is merely binding on the member states. And yet from early on in the UN's history there has been a sense that the purposes of the UN were so essential that non-member states could be bound by decisions of the member states. In the words of one authoritative treatise discussing the effect of the UN Charter on non-member states: 'as international society becomes a more integrated community, a departure from the accepted principle becomes unavoidable, in particular in the sphere of international peace and security. ${ }^{, 19}$ It seems that with regard to certain principles in the UN Charter this treaty can be seen as creating binding obligations on non-parties, but that this manoeuvre is probably dependent on the fact that those same Charter principles are now seen as binding customary international law. ${ }^{20}$

Applying this reasoning to Common Article 3 to the Geneva Conventions we might assume that the universal adherence to the Geneva Conventions together with the legal consensus that the Article applies as customary international law, ${ }^{21}$ allow us to conclude that this provision is indeed binding on armed groups. ${ }^{22}$ It is worth noting that the UK Ministry of Defence relies on the treaty as such and with reference to Common Article 3 states: 'This purports to bind all parties, both states and insurgents, whether or not the latter have made any declaration of intent to apply the principles. ${ }^{23}$ Similarly, the language of the International Court of Justice suggests that the Contras in Nicaragua were bound by the terms of Common Article 3 rather than merely by the principles which it embodied: 'The United States is thus under an obligation not to encourage

\footnotetext{
International Law concerning Friendly Relations and Co-operation among States in accordance with the Charter of the United Nations'. See Articles 96(3) and 1(4). This issue is dealt with again in the section on weapons.

${ }^{17}$ The Interaction Between Customary International Law and Treaties (supra) at 339.

${ }^{18}$ Dinstein 'At the present juncture, there is no decisive authority for holding a constitutive provision of a treaty applicable to insurgents who refuse to abide by it and deny the rights of the State to exercise its treaty-making power on their behalf.' Ibid. at 344.

${ }^{19}$ R. Jennings and A. Watts, (eds), Oppenheim's International Law, 9th edn, vol. I (London: Longman, 1996) at 1265.

${ }^{20}$ See M. Shaw, International Law, 6th edn, (Cambridge: Cambridge University Press, 2008) at 929.

${ }^{21}$ See Nicaragua $v$ United States of America International Court of Justice (1986) at paras. 218-220.

${ }^{22}$ Compare the Sierra Leone Special Court: 'It suffices to say, for the purpose of the present case, that no one has suggested that insurgents are bound because they have been vested with personality in international law of such a nature as to make it possible for them to be a party to the Geneva Conventions. Rather, a convincing theory is that they are bound as a matter of international customary law to observe the obligations declared by Common Article 3 which is aimed at the protection of humanity.' Appeals Chamber Decision on Challenge to Jurisdiction: Lomé Accord Amnesty, Case No. SCSL-2004-15-AR72(E) and SCSL-2004-16AR72(E) at para. 47, 13 March 2004.

${ }^{23}$ The Manual of the Law of Armed Conflict, (Oxford: Oxford University Press, 2004) at 385, fn 19.
} 
persons or groups engaged in the conflict in Nicaragua to act in violation of the provisions of Article 3 common to the four 1949 Geneva Conventions'. ${ }^{24}$

Before we simply apply this logic to all humanitarian law provisions applicable in internal armed conflict we need to admit that Common Article 3 was singled out by the International Court of Justice 'as a minimum yardstick ... rules which, in the Court's opinion, reflect ... "elementary considerations of humanity". ${ }^{25}$ While we can conclude that international law accepts that Common Article 3 is binding on non-state parties to a conflict, due perhaps to a combination of the special nature of the norms and the universal acceptance of the treaties, the case may be less certain for other norms found in treaties applicable in non-international armed conflicts. These treaties may enjoy less than universal adherence and the norms they detail may not always be considered as representing customary international law.

Consider Article 4(3)(c) of 1977 Additional Protocol II which reads 'children who have not attained the age of fifteen years shall neither be recruited in the armed forces or groups nor allowed to take part in hostilities'. This would seem to create an immediate set of obligations for any 'group' not to recruit such a child nor allow them to take part in hostilities. How can a treaty create such an obligation for an armed group? If the logic is similar to that for the application of Common Article 3, the treaty on its face expressly binds a third party and in any event is universal and an elemental consideration of humanity. But the treaty does not enjoy universal ratification, and in practical terms it is likely that lawyers will resort to customary international law or some accumulated set of obligations in order to prove the international individual criminal responsibility of the members of the group. This will particularly be the case where the armed conflict takes place in a state not a party to Protocol II or the tribunal has no particular jurisdiction over Protocol II. The tribunal may rely on a particular provision in its own statute or a generic category such as violations of the laws and customs of war.

Another set of treaties we need to consider are those relating to weapons. As with Protocol I, national liberation movements can make a declaration under the Convention on Prohibitions or Restrictions on the Use of Certain Conventional Weapons Which May be Deemed to be Excessively Injurious or to Have Indiscriminate Effects $(\mathrm{CCW}){ }^{26}$ Such a declaration can bring into force, not only the Weapons Convention and its Protocols, but also the Geneva Conventions, even where the state against which the liberation movement is fighting is not a party to 1977 Protocol I. ${ }^{27}$ No such Declaration has been successfully made either under this Convention or under 1977 Protocol I. ${ }^{28}$

Since 2001 the Convention has been amended so that it now reads: 'In case of armed conflicts not of an international character occurring in the territory of one of the High Contracting Parties, each party to the conflict shall be bound to apply the prohibitions and restrictions of this Convention and its annexed Protocols. ${ }^{29}$ This applies only in situations where the relevant state

\footnotetext{
${ }^{24}$ Nicaragua $v$ United States (supra) at para. 220.

${ }^{25}$ Ibid. at para. 218

${ }^{26} 10$ October 1980, see Art. 7(4).

${ }^{27}$ Art. 7(4)(b).

${ }^{28}$ Although certain declarations have been sent to the ICRC, the procedure demands a communication with the Swiss Federal authorities.

${ }^{29}$ Article 1(3),
} 
has ratified the amendment, in other cases the relevant provisions will only apply to inter-state conflicts, with the exception of the provisions in Amended Protocol II (Prohibitions or Restrictions on the Use of Mines, Booby-Traps and Other Devices) and Protocol V (Explosive Remnant of War). ${ }^{30}$ Other weapons treaties may or may not extend to situations of internal armed conflict but there are apparently no explicit provisions aimed at the non-state parties to the conflict. ${ }^{31}$ Despite the express inclusion of a need to prevent the use of cluster munitions by armed groups the new Convention on Cluster Munitions confines itself to a preambular commitment that the states parties are: 'Resolved also that armed groups distinct from the armed forces of a State shall not, under any circumstances, be permitted to engage in any activity prohibited to a State Party to this Convention'. Commentators have not seen this as creating any international obligations on the armed groups as such; nevertheless it has been argued that as the treaty refers to a ban on assistance to 'anyone' engaged in prohibited activities this must be read to include assistance to such armed groups. ${ }^{32}$ So states parties are prohibited under the treaty from assisting non-state actors to use cluster munitions, while the non-state actors themselves are not considered as subject to obligations under the same treaty.

This duality is not confined to weapons treaties. Even where a humanitarian treaty on the methods of war applies to the state party in an internal armed conflict, there may be doubts as to the generation of obligations for the armed non-state actor. Like Common Article 3, the 1954 Hague Convention for the Protection of Cultural Property in the Event of Armed Conflict seeks to single out a set of obligations for the non-state armed group. Article 19(1) states that 'each Party to the conflict shall be bound to apply, as a minimum, the provisions of the present Convention which relate to respect for cultural property.' But the 1999 Protocol II to the Hague Convention of 1954, while it extends to internal armed conflicts, seems to specifically address its key obligations to a state 'Party' (with a capital P) to the Protocol rather than the 'parties' to the conflict (with a small p). This exclusive capitalization for state 'Parties' is not present in the Geneva Conventions of 1949 nor in the Hague Convention of 1954. Article 1(a) to Protocol II, however, draws this distinction in unambiguous terms. 'For the purposes of this Protocol:

a. "Party" means a State Party to this Protocol'. Moreover the Protocol, while it is extended to non-international armed conflicts on the territory of a 'State Party' to the Protocol, ${ }^{33}$ nowhere demands substantive obligations from the non-state party as the obligations are addressed to Parties or a Party. The Protocol seems on its face and at first glance to address non-state actor 'parties' (with a small p) mainly to remind that the application of the Protocol to an internal armed conflict 'shall not affect the legal status of the parties to the conflict. ${ }^{34}$ This state-centric reading is, however, contradicted by Henckaerts, who participated in the drafting, and who writes that such 'a literal interpretation would lead to a manifestly absurd result of declaring a treaty

\footnotetext{
${ }^{30}$ Amended Protocol II states: '1(3.) In case of armed conflicts not of an international character occurring in the territory of one of the High Contracting Parties, each party to the conflict shall be bound to apply the prohibitions and restrictions of this Protocol.' Protocol V Article 1(3) 'This Protocol shall apply to situations resulting from conflicts referred to in Article 1, paragraphs 1 to 6, of the Convention, as amended on 21 December 2001.'

${ }^{31}$ See W.H. Boothby, Weapons and the Law of Armed Conflict, (Oxford: Oxford University Press, 2009) Ch. 18.

32 B. Docherty, 'Breaking New Ground: The Convention on Cluster Munitions and the Evolution of International Humanitarian Law', vol. 34 Human Rights Quarterly (2009) 934-63, at 959-962, esp. 960.

${ }^{33}$ Article 22.

${ }^{34}$ See Protocol II of 1999 to the Hague Convention of 1954 for the Protection of Cultural Property in the Event of Armed Conflict, articles 1 and 22(6), see also articles 22(7), 32(4) and 35(2). Note the provision for a party to a conflict to accept the protocol only applies to a 'State party', article 3(2).
} 
applicable to non-international armed conflicts and at the same time eliminating most of its practical relevance in such conflicts. ${ }^{35}$ According to Henckaerts' appreciation at the time: ${ }^{36}$

Although Article 22 of the Second Protocol does not spell it out as clearly as it could have, the Protocol applies to all parties to a non-international armed conflict, whether governmental or insurgent forces. This was clearly acknowledged at the final plenary session. A certain confusion arose because Article 1 of the Protocol defines the word "Party" as a State Party to the Second Protocol. However, the understanding was that throughout the text the word "Party" in the phrase "Party to the conflict" includes rebel groups of States party to the Second Protocol but not third States which have not ratified the Second Protocol. ${ }^{37}$ The reasoning was that non-governmental forces involved in a non-international armed conflict within a State party to the Protocol are bound by the Protocol through the ratification of the State concerned. ${ }^{38}$

While treaty law remains important, it can be ambiguous as to whether it binds non-state actors. In any event it remains unclear how a treaty obligation applies in international law to the non-state armed group through ratification by the state it is fighting against. It would seem that the question of customary international law has become determinant. Let us now see how custom is applied to armed non-state actors.

\section{B. Contemporary Customary International Law}

Inquiries into customary international humanitarian law have taken off in recent years, ${ }^{39}$ in part due to the perceived need to prove that certain obligations are customary so that they can form the basis for the prosecution of an individual for an international crime before an international criminal tribunal. Despite the articulation of certain crimes in the relevant Statutes the ad hoc International Criminal Tribunals have chosen to examine whether the events are covered by

\footnotetext{
35 'The Protection of Cultural Property in Non-International Armed Conflict', in L.Lijnzaad and N. van Woudenberg (eds.), Protecting Cultural Property in Armed Conflict: The First Ten Years of the Second Protocol to the Hague Convention of 1954 for the Protection of Cultural Property in the Event of an Armed Conflict (Leiden: Martinus Nijhoff Publishers, forthcoming 2010). See also R. O'Keefe, 'Protection of Cultural Property', in D. Fleck, (ed), The Handbook of Humanitarian Law in Armed Conflict, 2nd ed, (Oxford: Oxford University Press, 2007) 433-74 who separates the rules applicable in international and non-international armed conflict in a detailed examination.

${ }^{36}$ 'New rules for the protection of cultural property in armed conflict', vol. 835 International Review of the Red Cross (1999) 593620 at $618-9$.

${ }^{37}$ [Third States which have not ratified the Second Protocol are generally referred to as "party" (in lower case).] Footnote in the original.

${ }^{38}$ [It is unfortunate that recognition of the potential confusion of the definition of "Party" and the use of the term "Party to the conflict" came only in the last hours of the Diplomatic Conference. As a result, there was no discussion on whether the general understanding that the Second Protocol applies to governmental forces and rebel groups in a non-international armed conflict is also valid for Article 11(9). It is difficult to say whether this was indeed the intention of States, as the Working Group on Chapter 3 (Enhanced Protection) did not discuss the issue.] footnote in the original. Article 11(9) reads: '9. Upon the outbreak of hostilities, a Party to the conflict may request, on an emergency basis, enhanced protection of cultural property under its jurisdiction or control by communicating this request to the Committee. The Committee shall transmit this request immediately to all Parties to the conflict. In such cases the Committee will consider representations from the Parties concerned on an expedited basis. The decision to grant provisional enhanced protection shall be taken as soon as possible and, notwithstanding Article 26, by a majority of four-fifths of its members present and voting. Provisional enhanced protection may be granted by the Committee pending the outcome of the regular procedure for the granting of enhanced protection, provided that the provisions of Article 10 sub-paragraphs (a) and (c) are met.' Note according to Article 24 'The Committee for the Protection of Cultural Property in the Event of Armed Conflict is hereby established. It shall be composed of twelve Parties which shall be elected by the Meeting of the Parties.'

${ }^{39}$ See in this regard J.-M. Henckaerts and L. Doswald-Beck, Customary International Humanitarian Law - Three Volumes (Cambridge: Cambridge University Press, 2005).
} 
applicable customary international law, ${ }^{40}$ before going on to determine whether customary international law entails individual criminal responsibility. ${ }^{41}$

But the turn to custom is also essential beyond the question of individual prosecution and has been central in the context of fact-finding missions and commissions of inquiry charged with determining violations of international law by armed non-state actors. In contrast to many provisions of treaty law, customary international law will usually be binding on the non-state actor as such. ${ }^{42}$ In this context the work of the Darfur Commission is instructive. Here the Commission set a threshold for the capacity of any rebel group to bear international obligations under customary international law.

172. The SLM/A and JEM, like all insurgents that have reached a certain threshold of organization, stability and effective control of territory, possess international legal personality and are therefore bound by the relevant rules of customary international law on internal armed conflicts referred to above. The same is probably true also for the NMRD.

Turning to the question of prosecution of individuals we should note that, even where the Statute of an International Criminal Tribunal clearly spells out the obligations for an individual there may be questions as to whether the armed non-state actor can be considered to know of the applicability of such a norm. Although the first trial before the International Criminal Court was not asked to rule on whether the relevant crime was a violation of customary international law, the defence did ask the Court to rule on 'whether Thomas Lubanga Dyilo was aware of the existence of the crime of enlisting and conscripting children under the age of fifteen years and using them to participate actively in hostilities and whether he could foresee that the conduct in question was criminal in nature and could therefore entail his criminal responsibility. ${ }^{43}$ The PreTrial Chamber mentioned the finding by the Sierra Leone Special Court's Appeal Chamber that the prohibition on child recruitment had crystallized 'as a customary law norm'. ${ }^{44}$ But the Chamber seems to place more emphasis on the fact that the communities of Ituri 'were familiar with the Statute [even before its entry into force] and the type of conduct which gives rise to criminal responsibility under the Statute', ${ }^{45}$ and that in fact 'Kristine Peduto explained that on 30 May 2003 she discussed child protection issues and matters relating to the ratification of the Rome Statute by the DRC with Thomas Lubanga Dyilo., 46

We can surmise that, in the future, courts may be less inclined to search for evidence of customary law and treat the Rome Statute (or the relevant national laws) as significant for proving the illegality of the conduct in question, ${ }^{47}$ the question of legality turning more on the

\footnotetext{
${ }^{40}$ See Tadić (Appeal) (Decision on the defence motion for Interlocutory Appeal on Jurisdiction) ICTY, Appeals Chamber, Decision of 2 October 1995 (case no. IT-94-1-AR72) esp. paras. 94-127.

${ }^{41}$ Ibid. at paras. 128-136.

42 '[C]ustom may be opposable beyond States, not only to armed opposition groups but also to other non-State actors and individuals.' D. Bethlehem, "The methodological framework of the study", in E. Wilmshurst and S. Breua, (eds), Perspectives on the ICRC Study on Customary International Humanitarian Law, (Cambridge: Cambridge University Press, 2007) 3-14, at 8.

${ }^{43}$ Prosecutor $v$ Thomas Lubanga Dyilo, Decision on the confirmation of charges, 27 January 2007, at para. 294

${ }^{44}$ Ibid. at para. 311

${ }^{45}$ Ibid at para. 312.

${ }^{46}$ Ibid. at para. 313.

${ }^{47}$ See A. Cassese, 'The Statute of the International Criminal Court: Some Preliminary Reflections', vol. 10 European Journal of International Law (1999) 141-71, at 151-2.
} 
evident nature of the criminality of the action and the exposure of the individual to information about the norm in question. ${ }^{48}$

Despite the recent turn to customary international law as a source of obligation, we may have reached the limits of what this source of law can provide in answering our inquiry as to why non-state actors should be bound by international humanitarian law. States have traditionally consented to the emergence of customary international law as a system binding on themselves and other states because it is convenient for them to do so. Where these rules are also aimed at protecting human dignity and humanity in general it would seem that these rules can be binding on non-state actors (including individuals) where states intend to do this. Although it has sometimes been suggested that the behaviour of armed groups might form part of the practice which forms customary international law, few authorities have pursued this line of reasoning. We are left with the idea that customary international law binds those entities that states intend to bind and only creates those norms that states are ready to be bound by themselves. And to the extent that we are operating in the context of international humanitarian law there will be a degree of caution with regard to accepting new obligations in the context of non-international armed conflict where states clearly want to retain a degree of flexibility when fighting armed non-state actors,. The obvious consequence is that such reticence by states to expand the customary rules for themselves makes it hard to argue that the rules have become customary and create new binding obligations on the armed non-state actors. For example the authors of the Manual on the Law of Non-International Armed Conflict (produced by the International institute of International Humanitarian Law) include a rule which states that 'Children under the age of 18 may not participate actively in hostilities.' But they see the reticence of states in this area as preventing a simple conclusion that the norm is customary international law. The Commentary states: 'As to the age restriction, Article 4.3(c) Additional Protocol II requires that children who have not attained the age of 15 years shall not be allowed to take part in hostilities. The age limit was increased to 18 by the 2000 Optional Protocol to the Convention on the Rights of the Child on the Involvement of Children in Armed Conflict, which addresses both international and noninternational armed conflict. Although not necessarily reflective of customary law, the undesirability of children participating in conflict is generally recognized. ${ }^{, 49}$

It would be helpful therefore in terms of engaging with armed non-state actors to, as a first step, clarify which norms represent customary rules binding on them. Of course one set of rules can be found in the study on customary international humanitarian law, ${ }^{50}$ another much

\footnotetext{
${ }^{48}$ See A. Cassese, 'The Statute of the International Criminal Court: Some Preliminary Reflections', vol. 10 European Journal of International Law (1999) 141-71, at 151-2.

${ }^{49}$ International Institute of Humanitarian Law, San Remo, 2006, Article 3(5)(b). The Manual is considered a set of guidelines rather than reflective of rules of customary international law.

${ }^{50}$ J.-M. Henckaerts and L. Doswald-Beck, Customary International Humanitarian Law - Volume 1: Rules, (Cambridge: Cambridge University Press, 2005) and helpfully available online in summary form at J.-M. Henckaerts, 'Study on customary international humanitarian law: A contribution to the understanding and respect for the rule of law in armed conflict', vol. 857 International Review of the Red Cross (2005) 175-212. The methodology for finding customary obligations for non-state actors is not obvious, in fact where the existing human rights obligations of states have been used to divine customary humanitarian law for non-state actors this methodology has been criticized, for states may have only have intended to create obligations for themselves in this context:. R. Piotrowicz, 'Displacement and Displaced Persons', in E. Wilmshurst and S. Breua, (eds), Perspectives on the ICRC Study on Customary International Humanitarian Law, (Cambridge: Cambridge University Press, 2007) 337-53, at 340-341. Some of the transposition of obligations from states to armed non-state actors has been similarly criticized as 'aspirations rather than practical' in the context of the obligation to instruct armed forces in international humanitarian law; D. Turns, 'Implementation and compliance', in E. Wilmshurst and S. Breua, (eds), Perspectives on the ICRC Study on Customary International Humanitarian Law, (Cambridge: Cambridge University Press, 2007) 354-76, at 362. A more general caution is
} 
shorter list was attempted more recently in the Report of the International Commission of Inquiry on Darfur to the United Nations Secretary-General, 25 January 2005. The list is reproduced here together with the original footnotes.

(i) the distinction between combatants and civilians, and the protection of civilians, notably against violence to life and person, in particular murder ${ }^{51}$ (this rule was reaffirmed in some agreements concluded by the Government of the Sudan with the rebels) ${ }^{52}$;

(ii) the prohibition on deliberate attacks on civilians; ${ }^{53}$

(iii) the prohibition on indiscriminate attacks on civilians, ${ }^{54}$ even if there may be a few armed elements among civilians; ${ }^{55}$

expressed by M. Schmitt, 'The Law of Targeting', in E. Wilmshurst and S. Breua, (eds), Perspectives on the ICRC Study on Customary International Humanitarian Law, (Cambridge: Cambridge University Press, 2007) 131-68, at 135, Schmitt invites a comparison with the rules in the Manual on the Law of Non-International Armed Conflict, International Institute of Humanitarian Law, San Remo, 2006 (drafting committee: M.N. Schmitt, C.H.B. Garraway and Y. Dinstein).

${ }^{51}$ The rule is laid down in Common Article 3 of the 1949 Geneva Conventions, has been restated in many cases, and is set out in the 2004 British Manual on the Law of Armed Conflict (at $\S 15.6$ ). It should be noted that in the Report made pursuant to 5 of the UN Security Council resolution 837 (1993) on the investigation into the 5 June 1993 attack on UN Forces in Somalia, the UN Secretary-General noted that " The [Geneva] Conventions were designed to cover inter-State wars and large-scale civil wars. But the principles they embody have a wider scope. Plainly a part of contemporary international customary law, they are applicable wherever political ends are sought through military means. No principle is more central to the humanitarian law of armed conflict than the obligation to respect the distinction between combatants and non-combatants. That principle is violated and criminal responsibility thereby incurred when organizations deliberately target civilians or when they use civilians as shields or otherwise demonstrate a wanton indifference to the protection of non-combatants.”(UN doc. S/26351, 24 August 1993, Annex, § 12). According to a report of the Inter-American Commission on Human Rights on the human rights situation in Colombia issued in 1999, international humanitarian law prohibits "the launching of attacks against the civilian population and requires the parties to an armed conflict, at all times, to make a distinction between members of the civilian population and parties actively taking part in the hostilities and to direct attacks only against the latter and, inferentially, other legitimate military objectives." (Third Report on the Human Rights Situation in Colombia, Doc OAS/Ser.L/V/II.102 Doc. 9 rev.1, 26 February 1999, § 40). See also Tadić (ICTY Appeals Chamber), Decision on the Defence Motion for Interlocutory Appeal on Jurisdiction, (1995), §§ 98, 117, 132; Kordić and Cerkez, Case No. IT-95-14/2 (Trial Chamber III), Decision on the Joint Defence Motion toDismiss the Amended Indictment for Lack of Jurisdiction based on the limited Jurisdictional Reach of Articles 2 and 3, 2 March 1999, §§ 25-34 (recognizing that Articles 51(2) and 52(1) of Additional Protocol I and Article 13(2) of Additional Protocol II constitute customary international law).

${ }^{52}$ See Article 2 of the Humanitarian Cease Fire Agreement on the Conflict in Darfur, of 8 April 2004 (each Party undertakes to "refrain from any violence or any other abuse on civilian populations") as well as Article 2(1) of the Protocol on the Improvement of the Humanitarian Situation in Darfur, of 9 November 2004 (the Parties undertake "to take all steps required to prevent all attacks, threats, intimidation and any other form of violence against civilians by any Party or group, including the Janjaweed and other militias").

${ }^{53}$ See Tadić (Interlocutory Appeal), at $\S \S 100-102$. As the International Court of Justice held in its Advisory Opinion on Legality of the Threat or Use of Nuclear Weapons (at § 78), "States must never make civilians the object of attack". The general rule on the matter was restated and specified in Article 51(2) of the First Additional Protocol of 1977, whereby "The civilian population as such, as well as individual civilians, shall not be the object of attack. Acts or threats of violence the primary purpose of which is to spread terror among the civilian population are prohibited". A similar provision is contained in Article 13(2) of the Second Additional Protocol of 1977. These provisions, in the part concerning the intention to spread terror, may be held to have turned into customary law, if only because they ultimately spell out a notion inherent in the customary law prohibition of any deliberate attack on civilians. See also Article 8(2)(e)(i) of the ICC Statute and Article 4 (a) of the Statute of the Special Court for Sierra Leone. It should also be mentioned that in 1991, replying to a question in Parliament, the German Minister of Foreign affairs condemned "the continued military engagements of Turkish troops against the civilian population in Kurdish areas as a serious violations of international law"(in Bundestag, Drucksache, 12/1918, 14 January 1992, at 3).

Furthermore, in a communiqué concerning Rwanda issued in 1994, the French Ministry of Foreign Affairs condemned "the bombardments against civilian populations who have fled to Goma in Zaire...The attacks on the security of populations are unacceptable" (Communiqué of the Ministry of Foreign Affairs on Rwanda, 17 July 1994, in Politique étrangère de la France, July 1994, p. 101).

${ }^{54}$ This rule was held to be of customary nature in Tadić (Interlocutory Appeal), at $\S \S 100-102$, is restated and codified in Article 13 of Additional Protocol II, which is to be regarded as a provision codifying customary international law, and is also mentioned in the 2004 British Manual of the Law of Armed Conflict, at $\S 115.6 .5$ and 15.15-15.15.1.

${ }^{55}$ In a press release concerning the conflict in Lebanon, in 1983 the ICRC stated that "the presence of armed elements among the civilian population does not justify the indiscriminate shelling of women, children and old people." (ICRC, Press release no. 1474, Geneva, 4 November 1983). In 1997 in Tadić and ICTY Trial Chamber held that "it is clear that the targeted population [of a 
(iv) the prohibition on attacks aimed at terrorizing civilians; ${ }^{56}$

(v) the prohibition on intentionally directing attacks against personnel, installations, material, units or vehicles involved in a humanitarian assistance or peacekeeping mission in accordance with the Charter of the United Nations, as long as they are entitled to the protection given to civilians or civilian objects under the international law of armed conflict; 57

(vi) the prohibition of attacks against civilian objects; 58

(vii) the obligation to take precautions in order to minimize incidental loss and damage as a result of attacks, ${ }^{59}$ such that each party must do everything feasible to ensure that targets are military objectives ${ }^{60}$ and to choose means or methods of combat that will minimise loss of civilians; 61

(viii) the obligation to ensure that when attacking military objectives, incidental loss to civilians is not disproportionate to the military gain anticipated; 62

(ix) the prohibition on destruction and devastation not justified by military necessity; 63

(x) the prohibition on the destruction of objects indispensable to the survival of the civilian population; 64

crime against humanity] must be of predominantly civilian nature. The presence of certain non-civilian elements in the midst does not change the character of the population"' (judgment of 7 May 1997, at $\S 638$ and see also $\S 643$ ).

${ }^{56}$ See the 2004 British Manual of the Law of Armed Conflict, at $\S 15.8$.

${ }^{57}$ See $\S 3$ of the Security Council resolution 1502 (2003),83 as well as Article (8)(2)(e)(iii) of the ICC Statute and Article 4 (b) of the Statute of the Special Court for Sierra Leone);

${ }^{58}$ Pursuant $\S 5$ of General Assembly Resolution 2675 (XXV, of 9 December 1970), which was adopted unanimously and, according to the2004 British Manual of the Law of Armed Conflict, "can be regarded as evidence of State practice"(\$ 15-16.2), "dwellings and other installations that are used only by the civilian population should not be the object o military operations". See also the 2004 British Manual of the Law of Armed Conflict, at $\S \S 15.9$ and 15.9.1, 15.16 and 15.16.1-3);

${ }^{59}$ See the 2004 British Manual of the Law of Armed Conflict, at $\S \S 15.22-15.22 .1$.

${ }^{60}$ See Zoran Kupreškić and others, ICTY Trial Chamber, judgment of 14 January 2000, at $§ 260$.

${ }^{61}$ See for instance the Military Manual of Benin (Military Manual,1995, Fascicule III, pp. 11 and 14 ("Precautions must be taken in the choice of weapons and methods of combat in order to avoid civilian losses and damage to civilian objects...The direction and the moment of an attack must be chosen so as to reduce civilian losses and damage to civilian objects as much as possible”), of Germany (Military Manual, 1992, at §457), of Kenya (Law of Armed Conflict Manual, 1997, Precis no. 4, pp. 1 and 8), of Togo (Military Manual, 1996, Fascicule III, pp. 11 and 14), as well as the Joint Circular on Adherence to International humanitarian Law and Human Rights of the Philippines (1992, at §2 (c)). See also Zoran Kupreškić and others, ICTY Trial Chamber, judgment of 14 January 2000, at $§ 260$.

${ }^{62}$ In Zoran Kupreškić and others, an ICTY Trial Chamber held in 2000 that "Even if it can be proved that the Muslim population of Ahmici [a village in Bosnia and Herzegovina] was not entirely civilians but comprised some armed elements, still no justification would exist for widespread and indiscriminate attacks against civilians. Indeed, even in a situation of fullscale armed conflict, certain fundamental norms still serve to unambiguously outlaw such conduct, such as rules pertaining to proportionality." (judgment of 14 January 2000, at § 513).

See also some pronouncements of States. For instance, in 2002, in the House of Lords the British Government pointed out that, with regard to the civil war in Chechnya, it had stated to the Russian Government that military "operations must be proportionate and in strict adherence to the rule of law." (in 73 British Yearbook of International Law" 2002, at 955). The point was reiterated by the British Minister for trade in reply to a written question in the House of Lords (ibid., at 957). See also the 2004 British Manual of the Law of Armed Conflict, at $\S 15.22 .1$. in 1992, in a joint memorandum submitted to the UN, Jordan and the US stated that "the customary rule that prohibits attacks which reasonably may be expected at the time to cause incidental loss of civilian life, injury to civilians, damage to civilian objects, or a combination thereof, which would be excessive in relation to the concrete and direct military advantage anticipated, are prohibited" (UN doc. A/C.6/47/3, 28 September 1992, at $\S 1(\mathrm{~h})$ ). In a judgment of 9 December 1985, an Argentinean Court of Appeals held in the Military Junta case that the principle of proportionality constitutes a customary international norm on account of its repeated doctrinal approbation. Spain insisted on the principle of proportionality in relation to the internal armed conflicts in Chechnya and in Bosnia and Herzegovina ( see the statements in the Spanish Parliament of the Spanish Foreign Minister, in Activitades, Textos y Documentos de la Politica Exterior Espaňola, Madrid 1995, at 353, 473.In addition, see the 1999 Third Report on Colombia of the Inter-American Commission on Human Rights (Doc.OAS/Se.L/V/II.102 Doc.9, rev.1, 26 February 1999, at $\S 77$ and 79). See also the 1999 UN Secretary-General's Bulletin, § 5.5 (with reference to UN forces).

${ }^{63}$ Rome Statute, at Article 8(2)(e)(xii). See also the 2004 British Manual of the Law of Armed Conflict, at $\$$ 15.17- 15.17.2). Under Article 23(g) of the Hague Regulations, it is prohibited "to destroy or seize the enemy's property, unless such destruction or seizure be imperatively demanded by the necessities of war". The grave breaches provisions in the Geneva Conventions also provide for the prohibition of extensive destruction and appropriation of property, not justified by military necessity and carried out unlawfully and wantonly (see First Geneva Convention, Article 50 in fine; Second Geneva Convention, Article 51 in fine; Fourth Geneva Convention, Article 147 in fine; Additional Protocol I, Article 51(1) in fine.

${ }^{64}$ Article 14 of the Second Additional Protocol; as rightly stated in the 2004 British Manual of the Law of Armed Conflict, at $\$ 15.19 .1$, "the right to life is a non-derogable human right. Violence to the life and person of civilians is prohibited, whatever 
(xi) the prohibition on attacks on works and installations containing dangerous forces; 65

(xii) the protection of cultural objects and places of worship; 66

(xiii) the prohibition on the forcible transfer of civilians; ${ }^{67}$

(xiv) the prohibition on torture and any inhuman or cruel treatment or punishment; ${ }^{68}$

(xv) the prohibition on outrages upon personal dignity, in particular humiliating and degrading treatment, including rape and sexual violence; 69

(xvi) the prohibition on declaring that no quarter will be given; ${ }^{70}$

(xvii) the prohibition on ill-treatment of enemy combatants hors de combat and the obligation to treat captured enemy combatants humanely; ${ }^{71}$

(xviii) the prohibition on the passing of sentences and the carrying out of executions without previous judgment pronounced by a regularly constituted court, affording all the judicial guarantees recognized as indispensable by the world community; ${ }^{72}$

(xix) the prohibition on collective punishments; ${ }^{73}$

$(\mathrm{xx})$ the prohibition on the taking of hostages; ${ }^{74}$

(xxi) the prohibition on acts of terrorism; ${ }^{75}$

(xxii) the prohibition on pillage; ${ }^{76}$

(xxiii) the obligation to protect the wounded and the sick; 77

(xxiv) the prohibition on the use in armed hostilities of children under the age of $15 ;{ }^{78}$

Although these prohibitions would normally be seen as easily transposable to armed non-state armed groups, the idea of armed non-state actors creating a 'regularly constituted court', or

method is adopted to achieve it. It follows that the destruction of crops, foodstuffs, and water sources, to such an extent that starvation is likely to follow, is also prohibited.")

${ }^{65}$ Article 15. Additional Protocol II; see also the 2004 British Manual of the Law of Armed Conflict, at $\S 15.21$.

${ }^{66}$ Article 16, Additional Protocol II.

${ }^{67}$ Article 17, Additional Protocol II, Article 8(2)(e)(viii) of the Rome Statute, and referred to in the 2004 British Manual of the

Law of Armed Conflict, at $\S \S 15.14,15.14 .1-2)$.

${ }^{68}$ See common Article 3 (1) (a)).

${ }^{69}$ See common Article 3, (1) (c).

${ }^{70}$ See Article 8 (2) (e) (x) of the ICC Statute.

${ }^{71}$ See common Article 3(1) as well as the 2004 British Manual of the Law of Armed Conflict, at $§ 15.6 .4$.

${ }^{72}$ See common Article 3 (1) (d); see also General Comment 29 of the Human Rights Committee, at $\S 16$.

${ }^{73}$ See Article 4(b) of the Statute of the ICTR and Article 3 (b) of the Statute of the Special Court for Sierra Leone; see also General Comment 29 of the Human Rights Committee, at $\S 11$, according to which any such punishment is contrary to a peremptory rule of international law.

${ }^{74}$ See common Article 3 (1) (b) of the 1949 Geneva Conventions as well as Article 4 (c) of the Statute of the ICTR and Article 3 (c) of the Statute of the Special Court for Sierra Leone).

${ }^{75}$ Article 4 (2)(d), Additional Protocol II; Article 4 (d) of the Statute of the ICTR and Article 3 (d) of the Statute of the Special Court. In his Report on the establishment of the Special Court for Sierra Leone, the Secretary-General stated that violations of Article 4 of Additional Protocol II have long been considered crimes under customary international law. See also Galić, ICTY Trial Chamber, judgment of 5 December 2003, at $\$ 769$.

${ }^{76}$ Article 4 (2) (g), Additional Protocol II and Article 8(2)(e)(v) of the Rome Statute; see also the 2004 British Manual of the Law of Armed Conflict, at $\S \S 15.23-15.23 .1$.

${ }_{77}$ Common Article 3 (2) of the Geneva Conventions.

${ }^{78}$ There are two treaty rules that ban conscripting or enlisting children under the age of 15 years into armed forces or groups or using them to participate actively in hostilities (see Article 8 (2) (e)(vii) of the ICC Statute and Article 4 (c) of the Statute of the Special Court for Sierra Leone). The Convention on the Rights of the Child, at Article 38,104 and the Protocol to the Convention on the Rights of the Child on the Involvement of Children in Armed Conflicts raise the minimum age of persons directly participating in armed conflicts to 18 years, although not in mandatory terms ( Article 1 of the Protocol provides that "States Parties shall take all feasible measures to ensure that members of their armed forces who have not attained the age of 18 years do not take a direct part in hostilities"(emphasis added); Article 4 (1) contains a similar provision concerning rebels 104; Articles 2 and 3 regulate the recruitment of children under 18). It may perhaps be held that a general consensus has evolved in the international community on a minimum common denominator: children under 15 may not take an active part in armed hostilities. 
having the right to intern detainees, continues to confound scholars. ${ }^{79}$ Clearly a rebel group has no legal authority to constitute a court in the regular way that a government can. Nevertheless the practice shows that armed non-state actors do fashion a form of judicial process and will be judged against international standards in this field. Because these standards have to be gleaned from human rights law this is dealt with in more detail in the section on human rights law below. $^{80}$

\section{Rebellion, sedition, insurrection, civil war, and belligerency}

Before leaving this section on customary international law it is worth reprising some of the doctrine concerning the rules concerning recognized insurgencies or belligerents. In the past authors presented legal consequences under the laws of war drawn from the justness of the cause of those fighting the sovereign state and the extent to which those fighters had taken control. So for example rebellion and sedition might be seen as simply criminal whereas a just cause with significant control and support would be considered civil war with the full application of the laws of war, as if the fighting were between two nation states. Because modern humanitarian law has attempted to separate the causes of the war from the rules that should apply, and because this law has eschewed the idea that the law only applies once the non-state actors are recognized by the state, and finally because few governments today would countenance formally recognizing their non-state adversaries as either insurgents or belligerents, the historical approach is of limited relevance. ${ }^{81}$ But the terminology is still banded about, and, moreover, the reasoning behind its application remains pertinent. Why should a non-state actor inherit international rights and obligations? The following passage from Le droit des gens (first published in 1758) by the Swiss jurist Emer de Vattel illustrates quite nicely the early approach to these questions. The passage is admittedly long but is a refreshing reminder of the need to consider why we think it important to ensure greater ownership of the laws of war by all sides.

It is a question very much debated, whether a sovereign is bound to observe the common laws of war towards rebellious subjects who have openly taken up arms against him? A flatterer, or a prince of a cruel and arbitrary disposition, will immediately pronounce that the laws of war were not made for rebels, for whom no punishment can be too severe. Let us proceed more soberly ...

The name of rebels is given to all subjects who unjustly take up arms against the ruler of the society, whether their view be to deprive him of the supreme authority, or to resist his commands in some particular instance and to impose conditions on him.

\footnotetext{
${ }^{79}$ Commenting on Rule 100 in the ICRC Study Hampson writes: 'It is difficult to envisage many circumstances in which a nonState armed group would be able to afford detainees the due process guarantees contained in the Study.' For her 'it is difficult to see how any non-State armed group could ensure that a tribunal was established by law without implying some degree of recognition of legitimacy. To require that a group respect a rule that the State makes it impossible to to comply with makes a nonsense of the law.' F. Hampson, 'Fundamental Guarantees', in E. Wilmshurst and S. Breua, (eds), Perspectives on the ICRC Study on Customary International Humanitarian Law, (Cambridge: Cambridge University Press, 2007) 282-301, at 287 and fn 20. Seelalso

${ }^{80}$ See further S. Sivakumaran, 'Courts of Armed Opposition: Fair Trials or Summary Justice?', vol. 7 JICJ (2009) 489-513; J. Somer, 'Jungle justice: passing sentence on the equality of belligerents in non-international armed conflict', vol. 89 International Review of the Red Cross 867, (2007) 655-90.

${ }^{81}$ See for the detailed practice concerning recognition of insurgency and belligerency H. Lauterpacht, Recognition in International Law, (Cambridge: Cambridge University Press, 1947) 174-328.
} 
A popular commotion is a concourse of people who assemble in a tumultuous manner, and refuse to listen to the voice of their superiors, whether the design of the assembled multitude be levelled against the superiors themselves, or only against some private individuals. Violent commotions of this kind take place when the people think themselves aggrieved; and there is no order of men who so frequently give rise to them as the tax-gatherers. If the rage of the malcontents be particularly levelled at the magistrates, or others vested with the public authority, and they proceed to a formal disobedience or acts of open violence, this is called a sedition. When the evil spreads, - when it infects the majority of the inhabitants of a city or province, and gains such strength that even the sovereign himself is no longer obeyed, - it is usual more particularly to distinguish such disorder by the name of insurrection....

When a party is formed in a state, who no longer obey the sovereign, and are possessed of sufficient strength to oppose him, - or when, in a republic, the nation is divided into two opposite factions, and both sides take up arms, this is called a civil war. Some writers confine this term to a just insurrection of the subjects against their sovereign, to distinguish that lawful resistance from rebellion, which is an open and unjust resistance. ... The sovereign indeed never fails to bestow the appellation of rebels on all such of his subjects as openly resist him; but when the latter have acquired sufficient strength to give him effectual opposition, and to oblige him to carry on the war against them according to the established rules, he must necessarily submit to the use of the term "civil war"....

A civil war breaks the bands of society and government, or at least suspends their force and effect; it produces in the nation two independent parties, who consider each other as enemies, and acknowledge no common judge. Those two parties, therefore, must necessarily be considered as thenceforth constituting, at least for a time, two separate bodies, two distinct societies. Though one of the parties may have been to blame in breaking the unity of the state and resisting the lawful authority, they are not less divided in fact. Besides, who shall judge them? Who shall pronounce on which side the right or the wrong lies? On earth they have no common superior. They stand therefore in precisely the same predicament as two nations, who engage in a contest, and being unable to come to an agreement, have recourse to arms.

This being the case, it is very evident that the common laws of war, - those maxims of humanity, moderation, and honour ... ought to be observed by both parties in every civil war. For the same reasons which render the observance of those maxims a matter of obligation between state and state, it becomes equally and even more necessary in the unhappy circumstance of the two incensed parties lacerating their common country. Should the sovereign conceive he has a right to hang up his prisoners as rebels, the opposite party will make reprisals ... should he burn and ravage, they will follow his example; the war will become cruel, horrible, and every day more destructive to the nation. ${ }^{\mathbf{2}}$

In modern times states and their representatives will go to great lengths to avoid such intimations of just cause, loss of control, or equality of arms. We might recall the controversy over whether it could be said that Iraq had descended into 'civil war' following the 2003 international armed conflict, ${ }^{83}$ and that later there were even attempts to avoid the use of the term insurgents. ${ }^{84}$ Of course today the simple use of the terms does not alter the rights and responsibilities of the rebels, but the historical diversion reminds where these terms came from and why they resonate in different ways. Today to alter the rights and responsibilities of an armed non-state actor (beyond what they enjoy under custom or treaty law) the state would have to formally recognize the group as insurgents or belligerents. In such a case the terms of the recognition would spell out which rights and responsibilities were to be applied under international law. A recognition of

\footnotetext{
${ }^{82}$ The Law of Nations (1797), B. Kapossy and R. Whatmore (eds), T. Nugent (trans) (Indianapolis: Liberty Fund 2008) at 641-6.

83 'What Next?', D.L. Byman and K. M. Pollack, Washington Post, 20 August, 2006; 'Iraq's Civil War' J.D. Fearon, Foreign Affairs, March/April 2007.

${ }^{84}$ W. Safire, 'Language: Insurgent irresponsiveness', International Herald Tribune, 16 January 2006.
} 
belligerency would imply all the rights and responsibilities that would apply to a state in interstate conflict, including it would seem all those applicable to warfare on the high seas. ${ }^{85}$

Should the armed non-state actor succeed in creating a new state its internationally wrongful acts are attributed to that new state according to the suggested draft articles on state responsibility proposed by the International Law Commission. ${ }^{86}$ Should the armed non-state actor succeed in forming or joining the government the International Law Commission (ILC) has suggested that the acts are attributed in a similar way, but in this case their Commentary has suggested an exception to this rule:

However, the rule in paragraph 1 should not be pressed too far in the case of governments of national reconciliation, formed following an agreement between the existing authorities and the leaders of an insurrectional movement. The State should not be made responsible for the conduct of a violent opposition movement merely because, in the interests of an overall peace settlement, elements of the opposition are drawn into a reconstructed government. Thus, the criterion of application of paragraph 1 is that of a real and substantial continuity between the former insurrectional movement and the new Government it has succeeded in forming. ${ }^{87}$

This attempt to hold armed non-state actors internationally accountable through eventual state responsibility has been criticized by Jean D'Aspremont on the grounds that there is no legal evidence for such a rule, and, that in policy terms it makes sense to exclude such attribution to the state where 'a national reconciliation or power sharing agreement leads to democratic elections which eventually bring the rebels to power. ${ }^{88}$ For him:

if we assume that rebels are aware of the main rules of inter-State responsibility, one could argue that excluding the application of Article 10 in case of negotiated agreements between rebels and the government could entice rebels to use political negotiations to purge and expunge their seizure of power from its most atrocious and monstrous deeds. It is true that the exclusion of Article 10 in case of national reconciliation or power-sharing agreement does not bring about an exclusion of the individual criminal responsibility of the insurgents. However, exclusion of attribution in that situation can be interpreted as meaning that the manner in which the insurgency is carried out (especially with respect to international humanitarian law) is of no importance and may give the impression that the rebels have a blank check as to means of warfare to which to can resort. In that sense, the exclusion of Article 10 in situations of national reconciliation or powersharing agreements can backfire, as rebels may no longer feel deterred from resorting to inhuman means of warfare if negotiating an agreement with the government could ultimately bar accountability of the State in the international legal order. ${ }^{89}$

The efforts of the International Law Commission to squeeze the violations of international law by insurgents into a state-centric vision can therefore be considered problematic. Rather than focusing on the theoretical possibility of holding a state accountable for the acts of the insurgent group that went on to become the state - it is time to look at another way in which to say that the group themselves are the bearers of international obligations.

\footnotetext{
${ }^{85}$ G. Schwarzenberger, A Manual of International Law, (New York: Praeger 1967) at 76-8. 213-4.

${ }^{86}$ Article 10. Conduct of an insurrectional or other movement: 1 . The conduct of an insurrectional movement which becomes the new Government of a State shall be considered an act of that State under international law. 2. The conduct of a movement, insurrectional or other, which succeeds in establishing a new State in part of the territory of a pre-existing State or in a territory under its administration shall be considered an act of the new State under international law. See UN Doc. A/Res/56/83, adopted 12 December 2001, discussed in A. Clapham, 'Human rights obligations of non-state actors in conflict situations', vol. 88 International Review of the Red Cross 863, (2006) 491-523, at 508-9.

${ }^{87}$ Para. 7 in the Commentary to Article 10, A/56/10, "Report of the ILC", adopted at its 53 ${ }^{\text {rd }}$ session, 2001.

${ }^{88}$ J. D'Aspremont, 'Rebellion and State Responsibility: Wrongdoing by Democratically Elected Insurgents', vol. 58 ICLQ (2009) 427-42, at 437.

${ }^{89}$ Ibid. at 436-7.
} 


\section{Special Agreements, Unilateral Declarations, and Codes of Conduct}

A further source of international obligations may be found in the special agreements entered into by the armed non-state actor. Such agreements will not be applied where they conflict with peremptory norms of international law, which according to the International Tribunal for the former Yugoslavia includes 'most customary rules of international humanitarian law.' agreements are not always easy to find or monitor, ${ }^{91}$ but it has been suggested by the Tribunal for the former Yugoslavia that violations of such agreements can be the basis for international prosecutions where these agreements go beyond customary international law. ${ }^{92}$ Such agreements are encouraged by the Geneva Conventions which state in their Common Article 3 that 'The Parties to the conflict should further endeavour to bring into force, by means of special agreements, all or part of the other provisions of the present Convention'. The Hague Convention of 1954 arguably strengthens this obligation, converting the 'should' into a 'shall'. ${ }^{93}$ And the $\mathrm{CCW}$ reminds parties to a conflict involving an authority representing a people engaged in a national liberation struggle that 'The High Contracting Party and the authority may also agree to accept and apply the obligations of Additional Protocol I to the Geneva Conventions on a reciprocal basis. ${ }^{94}$

Such special agreements have been considered international agreements by the Darfur Commission of Inquiry and can be seen as giving rise to international rights and obligations. ${ }^{95}$ The Commission seems to limit international obligations to those rebel groups that have a sufficient degree of control to bear the obligations:

In addition, the SLM/A and the JEM possess under customary international law the power to enter into binding international agreements (so called jus contrahendum), have entered various internationally binding Agreements with the Government. In these Agreements the rebels have undertaken, among other things, to comply with humanitarian law. The NMRD concluded two Agreements with the Government of the Sudan on 17 December 2004, one on humanitarian access and the other on security issues in the war zone. In these Agreements the parties pledged to release prisoners of war and organize the voluntary repatriation of internally displaced persons and refugees. ${ }^{96}$

Unilateral declarations by armed non-state actors are of considerable relevance not only for the obvious sense of ownership but also for those seeking to ensure compliance with these promises. One can make the case that such a declaration, whether or not it is written and witnessed, could be considered binding under international law and therefore a further source of obligation; this would be the case even in a situation where the relevant treaty made no provision

\footnotetext{
${ }^{90}$ Tadić (Appeal) (Decision on the defence motion for Interlocutory Appeal on Jurisdiction) ICTY, Appeals Chamber, Decision of 2 October 1995 (case no. IT-94-1-AR72) at para. 143.

${ }^{91}$ For a useful set of references see C. Ewumbue-Monono, 'Respect for international humanitarian law by armed non-state actors in Africa ', vol. 88 International Journal of the Red Cross (2006) 905-24.

${ }^{92}$ Tadić (supra) at paras. 143-4.

93 'The Parties to the Conflict shall endeavour to bring into force, by means of special agreements, all or part of the other provisions of the present Convention.' Article 19(2) of the Hague Convention of 1958;

${ }^{94}$ Article 7(4).

95 'All the parties to the conflict (the Government of the Sudan, the SLA and the JEM) have recognised that this is an internal armed conflict. Among other things, in 2004 the two rebel groups and the Government of the Sudan entered into a number of international agreements, inter se, in which they invoke or rely upon the Geneva Conventions.' Report of the International Commission of Inquiry on Darfur to the United Nations Secretary-General, 25 January 2005 at para. 76; and see paras. 168-171, and 173 for an application of the principles of international humanitarian law through the special agreements.

${ }^{96}$ Ibid. at para. 174.
} 
for declarations with the depositary. In the words of Klabbers: ${ }^{97}$ 'Of course, non-state entities may make unilateral declarations even in the absence of a specific provision to that effect, and following general international law, it may very well be that by making unilateral declarations those entities bind themselves on the international level. ${ }^{98}$,

These unilateral declarations are often at a level of generality, for example agreeing to respect humanitarian law. The ICRC has recently proposed that where an armed group has made such a unilateral declaration 'the development of a code of conduct that includes IHL can be suggested as a logical "next step". 99 Key here is the need to reduce the obligations down to a workable list. According to Sassòli: 'a declaration by an armed group that it will comply with "the Geneva Conventions and Additional Protocols" deserves scepticism. There are some 500 articles in those treaties! Often, a two page code of conduct is preferable, which really addresses the genuine humanitarian issues that arise for a given armed group in the field. ${ }^{100}$

One study of eleven such codes with regard to Afghanistan, Angola, Burundi, Democratic Republic of the Congo, Democratic People's Republic of Korea, Liberia, Sierra Leone, Somalia, Sudan, the Russian Federation and East and West Timor revealed that 'for non-State actors, the agreements refer to international human rights customary law', ${ }^{101}$ and that all the agreements state that the beneficiaries of humanitarian aid are to enjoy the following rights:

- the right to live in security and dignity,

- the right to basic needs, the right to receive humanitarian assistance without discrimination and according to basic needs,

- the right to be involved in humanitarian activities of concern to them,

- the right to legal and effective human rights protection,

- and the right to protection against forced population transfer. ${ }^{102}$

\section{E. When will an armed non-state actor be the bearer of these international obligations?}

Having established that armed non-state actors have international obligations that can stem from treaty law, customary international law, special agreements and unilateral declarations we still have to consider when exactly these obligations will attach to the group in question. A first question concerns the issue of attribution. There will be complex questions to answer with regard to which acts of which individuals can be attributed to the group so that the armed group as such

\footnotetext{
97 '(I Can't Get No) Recognition: Subjects Doctrine and the Emergence of Non-State Actors', (supra).

${ }^{98}$ Footnote in the original reads: 'As much follows from in particular the Nuclear Tests cases (Australia v France, and New Zealand v France), ICJ Reports (1986) at 253 and 457. But see the Case concerning the Frontier Dispute (Burkina Faso/ Republic of Mali), ICJ Reports (1986) 554, in which the Court held that unilateral declarations may not automatically be presumed to create binding commitments if there was a more obvious way to create such commitments, for instance through a negotiating process.'

${ }^{99}$ ICRC, Increasing Respect for International Humanitarian Law in Non-International Armed Conflicts, (Geneva: ICRC, 2008) at 22.

${ }^{100}$ M. Sassòli, 'The Implementation of International Humanitarian Law: Current and Inherent Challenges', in vol. 10 Yearbook of International Humanitarian Law (2007) 45-73, at 64

101 J.-D. Vigny and C. Thompson, "Fundamental standards of humanity: What future?", Netherlands Quarterly of Human Rights, Vol. 20, 2002, pp. 185-99, p. 193. See also Ends and Means: Human Rights Approaches to Armed Groups, International Council on Human Rights Policy (ICHRP), Versoix, 2000, p. 52. See also J. M. Weinstein, Inside Rebellion: The Politics of Insurgent Violence, (Cambridge: Cambridge University Press, 2006).

${ }^{102}$ Ibid., p. 194.
} 
is in violation of international humanitarian law. While considerable case-law exists explaining when states are responsible for the acts of their agents or those under their control and direction, very little thinking has been done with regard to non-state actors and when they might be responsible for the acts of their 'officials'.

A second question concerns the preconditions for the application of humanitarian law. Common Article 3 and 1977 Protocol II apply to certain types of non-international armed conflict where the violence has reached a certain threshold. The test in customary international law is similar. This is not the place to go into detail but a citation from the case-law of the ICTY may be helpful to understanding the threshold.

The criterion of protracted armed violence has therefore been interpreted in practice, including by the Tadić Trial Chamber itself, as referring more to the intensity of the armed violence than to its duration. Trial Chambers have relied on indicative factors relevant for assessing the "intensity" criterion, none of which are, in themselves, essential to establish that the criterion is satisfied. These indicative factors include the number, duration and intensity of individual confrontations; the type of weapons and other military equipment used; the number and calibre of munitions fired; the number of persons and type of forces partaking in the fighting; the number of casualties; the extent of material destruction; and the number of civilians fleeing combat zones. The involvement of the UN Security Council may also be a reflection of the intensity of a conflict. ${ }^{104}$

A second criterion is, however, required for the application of humanitarian law in a noninternational armed conflict to a non-state armed group. The armed non-state actor has to fulfill certain organizational requirements. ${ }^{105}$ While these might be more demanding in the text of Protocol II, in a way hinting at the sense control essential to the older concept of civil war, the requirements have most recently been spelt out in some detail by the ICTY.

These cases highlight the principle that an armed conflict can exist only between parties that are sufficiently organized to confront each other with military means. State governmental authorities have been presumed to dispose of armed forces that satisfy this criterion. As for armed groups, Trial Chambers have relied on several indicative factors, none of which are, in themselves, essential to establish whether the "organization" criterion is fulfilled. Such indicative factors include the existence of a command structure and disciplinary rules and mechanisms within the group; the existence of a headquarters; the fact that the group controls a certain territory; the ability of the group to gain access to weapons, other military equipment, recruits and military training; its ability to plan, coordinate and carry out military operations, including troop movements and logistics; its ability to define a unified military strategy and use military tactics; and its ability to speak with one voice and negotiate and conclude agreements such as cease-fire or peace accords. ${ }^{106}$

In order for international humanitarian law to apply to the armed non-state actor these two criteria (protracted armed violence and organization) need to be satisfied. In the absence of humanitarian law questions, issues will nevertheless arise concerning human rights law.

\footnotetext{
${ }^{103}$ For an exception see J.K. Kleffner, 'The collective accountability of organized armed groups for system crimes ', in A. Nollkaemper and H. van der Wilt, (eds), System Criminality in International Law, (Cambridge: Cambridge University Press, 2009) 238-69.

${ }^{104}$ Prosecutor v Haradinaj, Case No. IT-04-84-84-T, 3 April 2008, para. 49; see also S Vité, 'Typology of armed conflicts in international humanitarian law: legal concepts and actual situations', vol. 91 International Review of the Red Cross 873, (2009) 69-94.

${ }^{105}$ We saw above how the Darfur Commission introduced such a threshold to distinguish the groups fighting in Darfur

${ }^{106}$ Ibid. at para. 60. And see further ICTY Prosecutor v Boskoski Case No. IT-04-82, 10 July 2009, para. 175.
} 


\section{INTERNATIONAL HUMAN RIGHTS LAW}

While it may be seen as 'well settled' that international humanitarian law is applicable to the armed non-state actor party to an internal armed conflict, there is an apparent problem with the application of human rights law to such armed groups. This is for three main reasons.

First, because, in contrast to international humanitarian law, human rights law is seen in the doctrine as applicable only to states and is ill-suited to regulating the non-state actors. Second, human rights treaties only rarely address armed non-state armed groups. ${ }^{107}$ Third, there is a perception that engaging with rebel groups on human rights issues lends such groups a certain legitimacy. This is in part related to the first issue: by claiming that a group has violated human rights one is implying that they are a state-like entity because it is presumed that only states have human rights obligations. Let us look at these obstacles in turn.

Several commentators insist that only states have human rights obligations in this context, and that the non-state actors are exclusively bound by international humanitarian law. Moir, for example accepts the full application of humanitarian obligations for insurgents, but is adamant that such non-State actors have no human rights obligations: 'Human rights obligations are binding on governments only, and the law has not yet reached the stage whereby, during internal armed conflict, insurgents are bound to observe the human rights of government forces, let alone of opposing insurgents. Non-governmental parties are particularly unlikely to have the capacity to uphold certain rights (e.g. the duty to ensure a 'regularly constituted' court, the right to due process, being unlikely to have their own legal system, courts, etc.). ${ }^{108}$ Hampson has suggested that there is little legal as opposed to political evidence that human rights law applies to armed non-state actors, and, that if we assume that human rights law is based on the relationship between the individual and the authorities, then 'there may be an assumption that the individual owes some measure of loyalty to those authorities, to the extent of accepting the legal character of the rules they promulgate. Such authorities could legitimately punish attempts to overthrow them. Does Colombia, for example, really accept that the FARC can legitimately criminalize opposition to itself on the part of individuals living in areas under their control? ${ }^{109}$ Zegveld considers the issue but seems to exclude the application of human rights law on the grounds that: 'The main feature of human rights is that these are rights that people hold against the state only. ${ }^{110}$ Sassòli and Olson make a more pragmatic argument in the particular context of detention:

Application of human rights seems to make it impossible for one party to an armed conflict - the non-state actor - to intern legally. Parties to armed conflicts intern persons, hindering them from continuing to bear arms, so as to gain the military advantage. If the non-state actor cannot legally intern, it is left with little option - for it is a serious violation of humanitarian law to deny quarter - but to release the captured enemy

\footnotetext{
107 The exception being the Optional Protocol to the Convention on the Rights of the Child, delat with in section VII below.

${ }^{108}$ L. Moir, The Law of Internal Armed Conflict, (Cambridge: Cambridge University Press 2002) 194.

${ }^{109}$ F. Hampson, 'Other areas of customary law in relation to the Study', in E. Wilmshurst and S. Breua, (eds), Perspectives on the ICRC Study on Customary International Humanitarian Law, (Cambridge: Cambridge University Press, 2007) 50-73, at 55-6 at fn 17.

${ }^{110}$ L. Zegveld, Accountability of Armed Opposition Groups in International Law, (Cambridge: Cambridge University Press 2002) 53.
} 
fighters. However, if rules applicable to armed conflict make efficient fighting impossible, they will not be respected, undermining any protection the law provides. ${ }^{111}$

While political scientists have studied the reasons why certain groups may commit atrocities, ${ }^{112}$ and humanitarians see the case of negotiating with such groups to reduce such abuses, lawyers have done hardly any work in developing a theory as to why such groups might have human rights obligations at all. And where some human rights obligations might be admitted such obligations are seen as problematic: as the actors will either not have the facilities to ensure respect for rights such as those associated with fair trial, or the human rights obligations with regard to liberty of the person will make 'efficient fighting impossible'.

As we have seen, however, the existing theories which attempt to explain the application of international humanitarian law to non-state actors are themselves rather lacking. To point to the fact that Common Article 3 addresses each 'Party' does little to explain how an inter-state treaty can bind a third party that might not wish to be bound. To explain in the alternative that the treaty binds all entities and individuals within the jurisdiction is less than convincing, especially where the entity at issue rejects not only the legitimacy of the state to enter into international obligations that would bind the non-state actor, but also rejects the operation of any such obligations through the medium of national law which too is often rejected as illegitimate. ${ }^{113}$ Even if the theory is satisfactory for some, it can hardly be seen as useful for generating a sense of ownership over the norms in question: 'you the insurgents should respect these norms because the state you are fighting against has ratified a treaty and created obligations for you through the medium of its national law.'

Whereas the assumption that international humanitarian law binds armed non-state actors dates back some time (and arguably to the older practice of recognizing insurgency and civil war) the argument that armed non-state actors are bound by international human rights law has only recently been made with conviction. Fleck puts it as follows:

Whereas the binding effect of international humanitarian law on non-state actors was never seriously disputed, the extent to which this would also apply to underlying human rights norms was shadowed by a widely believed myth according to which human rights could be claimed against the state, but not against individuals. That myth may have been supported by a limited textual understanding of human rights conventions, but was never keeping with custom, neither with practice, and cannot be upheld. ${ }^{114}$

At the doctrinal level the application 'in principle' of human rights treaties has been recently recognized by Greenwood who similarly writes:

The obligations created by international humanitarian law apply not just to states but to individuals and to non-state actors such as a rebel faction or secessionist movement in a civil war. The application to non-state

\footnotetext{
${ }^{111}$ M. Sassòli and L. Olson, 'The relationship between international humanitarian law and human rights law where it matters: admissible killing and internment of fighters in non-international armed conflicts', vol. 90 International Review of the Red Cross $871,(2008) 599-627$, at 622-3, footnotes omitted.

112 J. M. Weinstein, Inside Rebellion: The Politics of Insurgent Violence, (Cambridge: Cambridge University Press 2007).

${ }^{113}$ See further M Sassòli, 'Transnational Armed Groups and International Humanitarian Law', (Harvard University: Program on Humanitarian Policy and Conflict Research 2006).

${ }^{114}$ D. Fleck, 'The Law of Non-international Armed Conflicts', in D. Fleck, (ed), The Handbook of Humanitarian Law in Armed Conflict, 2nd ed, (Oxford: Oxford University Press, 2007) 605-33.
} 
actors of human rights treaties is more problematic and even if they may be regarded as applicable in principle, the enforcement machinery created by human rights treaties can normally be invoked only in proceedings against a state. ${ }^{115}$

Leaving aside the question of the enforcement machinery we can suggest, along with several other commentators, ${ }^{116}$ that international human rights principles are increasingly considered applicable to parties to armed non-state actors. The doctrinal debate continues but the assumptions may be changing. This is due in part to recent UN practice with regard to human rights reports on non-state actors by Special Rapporteurs of the Human Rights Council and demands by the Security Council for armed groups to respect human rights (discussed in more detail below). ${ }^{117}$ Furthermore we should recall the reports of the various truth commissions (such as those in Guatemala and Sierra Leone) which detail the human rights violations committed by the relevant armed non-state actors.

It is suggested here that the most promising theoretical basis for human rights obligations for non-state actors is first, to remind ourselves that the foundational basis of human rights is best explained as rights which belong to the individual in recognition of each person's inherent dignity. The implication is that these natural rights should be respected by everyone and every entity. Moreover we should recall that the Universal Declaration of Human Rights is written as a proclamation of rights for everyone, the precise obligations of states were not agreed at that time. The word 'state' hardly appears at all in the Declaration. Rather than focusing on treaties or custom it makes more sense here to focus in the Declaration as the appropriate Universal Standard. As we shall see, in practice human rights accountability has been more focused on the application of such universal standards rather than the traditional sources of treaty and custom. ${ }^{118}$

With regard to the apparent absence to human rights treaties addressed to non-state actors we need to look at three more recent treaties. First, let us consider one of the most relevant norms concerning child soldiers. Article 4 to the Optional Protocol to the Convention on the Rights of the Child (2000) reads:

1. Armed groups that are distinct from the armed forces of a State, should not, under any circumstances, recruit or use in hostilities persons under the age of 18 years.

2. States Parties shall take all feasible measures to prevent such recruitment and use, including the adoption of legal measures necessary to prohibit and criminalize such practices.

\footnotetext{
115 'Scope of Application of Humanitarian Law' in D. Fleck (ed), The Handbook of Humanitarian Law in Armed Conflict, 2nd ed, (Oxford: Oxford University Press, 2007) 45-78 at 76.

${ }^{116}$ See also: E. Crawford, The Treatment of Combatants and Insurgents under the Law of Armed Conflict, (Oxford: Oxford University Press, 2010) at 126-129; C. Tomuschat, 'The Applicability of Human Rights Law to Insurgent Movements', in H. Fischer, U. Froissart, W. Heintschel von Heinegg, and C. Raap (eds), Krisensicherung und Humanitärer Schutz - Crisis Management and Humanitarian Protection: Festschrift für Dieter Fleck, (Berlin: Berliner Wissenschafts-Verlag, 2004) 573-91; D. Fleck, 'Humanitarian Protection Against Non-State Actors', in J.A. Frowein, K. Scharioth, I. Winkelmann, and R. Wolfrum (eds), Verhandeln für den Frieden - Negotiating for Peace: Liber Amicorum Tono Eitel, (Berlin: Springer, 2003) 69-94; Institute of International Law, L'application du droit international humanitaire et des droits fondamentaux de l'homme dans les conflits armés auxquels prennent part des entités non étatiques: résolution de Berlin du 25 août 1999 - The application of international humanitarian law and fundamental human rights in armed conflicts in which non-state entities are parties : Berlin resolution of 25 August 1999 (commentaire de Robert Kolb) Collection "résolutions" $n^{\circ}$ 1, (Paris: Pedone, 2003).

${ }^{117}$ See eg Resolutions 1193, 1213, 1214, 1216, 1471, 1479, 1509, and 1528 discussed in 'Human rights obligations of armed nonstate actors in conflict situations (supra) at 499-504.

${ }^{118}$ On the notion that standards represent a separate source of international law see E. Riedel, 'Standards and Sources: Farewell to the Exclusivity of the Sources Triad in International Law?', vol. 2 EJIL (1991) 58-84.
} 
3. The application of the present article under this Protocol shall not affect the legal status of any party to an armed conflict.

It has been suggested that the use of the word 'should' with regard to the injunction on the armed groups means that they have something less than a full immediate international obligation. States are said by some to be expressing a desire rather than a command. ${ }^{119}$ Nevertheless, one could interpret the assertion that children should not be recruited or used 'under any circumstances' as a clear indication that the drafters intended to create (or crystallize) a meaningful obligation that allows for no delay or derogation.

The International Convention for the Protection of All Persons from Enforced Disappearance (2006) includes an article which states that 'Each State Party shall take appropriate measures to investigate acts defined in article 2 [enforced disappearances by state agents] committed by persons or groups of persons acting without the authorization, support or acquiescence of the State and to bring those responsible to justice.' Although there were moments in the negotiations where it seemed as though enforced disappearances would be defined to include acts committed by non-state armed groups this did not happen and the obligation is clearly addressed only to states. Of course the international crime against humanity (rather than the treaty crime defined in this Convention) can still be committed by an individual operating within an armed non-state armed group where the enforced disappearance is 'part of a widespread or systematic attack directed against any civilian population, with knowledge of the attack' and that group is considered a 'political organization' in the words of the Statute of the International Criminal Court. ${ }^{120}$

The African Union Convention for the Protection and Assistance of Internally Displaced Persons in Africa (Kampala Convention) (2009) is perhaps the most explicit treaty to date with regards to what is expected of armed non-state actors. The first point to note is that two different types of actors are included in the scope of the treaty. According to Article 1(d) of the treaty "'Armed Groups" means dissident armed forces or other organized armed groups that are distinct from the armed forces of the state'; and under Article 1(n) "Non-state actors" means private actors who are not public officials of the State, including other armed groups not referred to in article 1(d) above, and whose acts cannot be officially attributed to the State'. The obligations for the members of the armed groups and the non-state actors are distinguished. The treaty states that:

Members of armed groups shall be prohibited from:

a. Carrying out arbitrary displacement;

b. Hampering the provision of protection and assistance to internally displaced persons under any circumstances;

c. Denying internally displaced persons the right to live in satisfactory conditions of dignity, security, sanitation, food, water, health and shelter; and separating members of the same family;

d. Restricting the freedom of movement of internally displaced persons within and outside their areas of residence;

e. Recruiting children or requiring or permitting them to take part in hostilities under any circumstances;

f. Forcibly recruiting persons, kidnapping, abduction or hostage taking, engaging in sexual slavery and trafficking in persons especially women and children;

\footnotetext{
${ }^{119}$ For references to different opinions over the effect of this provision of the Optional Protocol see Clapham, A., Human Rights Obligations of Non-State Actors (Oxford: Oxford University Press, 2006), p. 75; see also UNICEF and Coalition to Stop the Use of Child Soldiers, Guide to the Optional Protocol on the Involvement of Children in Armed Conflict, (New York: UNICEF, 2003), p. 17.

${ }^{120}$ See Statute of the International Criminal Court 1998 Article 7(1)(d) and 7(2)(i).
} 
g. Impeding humanitarian assistance and passage of all relief consignments, equipment and personnel to internally displaced persons;

h. Attacking or otherwise harming humanitarian personnel and resources or other materials deployed for the assistance or benefit of internally displaced persons and shall not destroy, confiscate or divert such materials; and

i. Violating the civilian and humanitarian character of the places where internally displaced persons are sheltered and shall not infiltrate such places. ${ }^{121}$

On the other hand states parties under the treaty shall:

h. Ensure the accountability of non-State actors concerned, including multinational companies and private military or security companies, for acts of arbitrary displacement or complicity in such acts;

i. Ensure the accountability of non-State actors involved in the exploration and exploitation of economic and natural resources leading to displacement.

The bigger point here is that these three human rights treaties have started developing their own terminology for armed non-state actors, and the terms are not dependent on the relatively demanding criteria set out in international humanitarian law. There is no suggestion that the group needs to be as organized or be engaged in the level of violence required for it to be considered a 'Party to the conflict' under international humanitarian law. Nevertheless, the treaties, while they expand beyond simply focusing on the behaviour of the state and its agents, do not explicitly address the armed groups in the same direct way that humanitarian law treaties do.

Turning to the legitimacy question, this still dogs the discussion. The African Union Convention is careful to include references to avoid the treaty ever being used as proof of legitimacy for the groups addressed. 'The provisions of this Article shall not, in any way whatsoever, be construed as affording legal status or legitimizing or recognizing armed groups and are without prejudice to the individual criminal responsibility of the members of such groups under domestic or international criminal law. ${ }^{122}$ The emphasis reflects not only the importance attached to the issue, but also how apparently simple it is to dispel the spectre of legitimacy with simple treaty language. Now that human rights treaties have started to address the behaviour (and obligations) of armed non-state actors it seems likely that such a savings clause will be considered enough to eliminate any legitimacy fears in the future. ${ }^{123}$ Human rights treaties could address armed groups in the same language that humanitarian law treaties address parties to the conflict. $^{124}$ In both situations a simple provision precluding any legitimacy implications will be enough to see off any legitimacy implications that might be drawn from the existence of the treaty.

\footnotetext{
${ }^{121}$ Article 7 (5)

${ }^{122}$ Article 7(1)

${ }^{123}$ Note the Convention suggests that the states intended to set out obligations for the non-state actors: 'The objectives of this Convention are to: ... (e) 'Provide for the respective obligations, responsibilities and roles of armed groups, non-state actors and other relevant actors, including civil society organizations, with respect to the prevention of internal displacement and protection of, and assistance to, internally displaced persons.'

${ }^{124}$ See for a recent example: Article 1(6) of the Amended Protocol II of 1996 to the CCW: "The application of the provisions of this Protocol to parties to a conflict, which are not High Contracting Parties that have accepted this Protocol, shall not change their legal status or the legal status of a disputed territory, either explicitly or implicitly.'
} 


\section{A. UN Special Mechanisms on Human Rights and Non-State Armed Groups}

Some governments have suggested that the UN's human rights bodies and mechanisms have no mandate in times of armed conflict. This suggestion has been convincingly refuted and need not detain us here. ${ }^{125}$ It is quite clear that the UN and its mechanisms are now reporting on human rights and humanitarian law violations in times of armed conflict. What concerns us in the present context is the ways in which these mechanisms have addressed human rights violations committed by armed non-state actors. Despite the apparent absence of clear obligations in the human rights treaties, the UN Special mechanisms have had to address the human rights obligations of armed non-state actors.

Let us consider again the work of the UN Darfur Commission of Inquiry. Although most of the report naturally concentrates on questions of international humanitarian law and war crimes some rebel activity is dealt with as a question of human rights obligations. At one point the report states that: 'Abduction of persons by the rebels also constitute serious and gross violations of human rights, and amount to enforced disappearance, but the Commission did not find any evidence that they were either widespread or systematic in order to constitute a crime against humanity.'126 Abduction is labeled a human rights violation even in the absence of a state actor.

The UN's Special Rapporteur on Extrajudicial, Summary or Arbitrary Executions, Philip Alston, grappled with the question in the context of his report on Sri Lanka. He concluded in the following terms:

Human rights law affirms that both the Government and the LTTE must respect the rights of every person in Sri Lanka. Human rights norms operate on three levels - as the rights of individuals, as obligations assumed by States, and as legitimate expectations of the international community. The Government has assumed the binding legal obligation to respect and ensure the rights recognized in the International Covenant on Civil and Political Rights (ICCPR). As a non-State actor, the LTTE does not have legal obligations under ICCPR, but it remains subject to the demand of the international community, first expressed in the Universal Declaration of Human Rights, that every organ of society respect and promote human rights. ${ }^{127}$

I have previously noted that it is especially appropriate and feasible to call for an armed group to respect human rights norms when it 'exercises significant control over territory and population and has an identifiable political structure'. This visit clarified both the complexity and the necessity of applying human rights norms to armed groups. The LTTE plays a dual role. On the one hand, it is an organization with effective control over a significant stretch of territory, engaged in civil planning and administration, maintaining its own form of police force and judiciary. On the other hand, it is an armed group that has been subject to proscription, travel bans, and financial sanctions in various Member States. The tension between these two roles is at the root of the international community's hesitation to address the LTTE and other

\footnotetext{
${ }^{125}$ P Alston, J Morgan-Foster, and Abresch William, 'The Competence of the UN Human Rights Council and its Special Procedures in relation to Armed Conflicts: Extrajudicial Executions in the 'War on Terror', vol. 19 EJIL 1, (2008) 183.

126 At para. 413.

${ }^{127}$ Footnote in the original reads: "14 Consistent with this analysis, the LTTE-created North East Secretariat on Human Rights released the final version of the NESOHR Charter of human rights in Oct. 2005. Its stated objectives include promoting respect for human rights 'according to the Universal Declaration of Human Rights and the International Covenants on human rights ...'.' Available at http://nesohr.org/charter/Charter-English.PDF.
} 
armed groups in the terms of human rights law. The international community does have human rights expectations to which it will hold the LTTE, but it has long been reluctant to press these demands directly if doing so would be to 'treat it like a State'.

It is increasingly understood, however, that the human rights expectations of the international community operate to protect people, while not thereby affecting the legitimacy of the actors to whom they are addressed. The Security Council has long called upon various groups that Member States do not recognize as having the capacity to formally assume international obligations to respect human rights. ${ }^{128}$ The LTTE and other armed groups must accept that insofar as they aspire to represent a people before the world, the international community will evaluate their conduct according to the Universal Declaration's 'common standard of achievement'. ${ }^{129}$

Alston goes on to include specific human rights recommendations addressed to the non-State actor: 'The LTTE should refrain from violating human rights, including those of non-LTTEaffiliated Tamil civilians. This includes in particular respect for the rights to freedom of expression, peaceful assembly, freedom of association with others, family life, and democratic participation, including the right to vote. The LTTE should specifically affirm that it will abide by the North-East Secretariat on Human Rights charter. ${ }^{130}$

This approach is reprised in the joint report on Lebanon and Israel by a group of four UN Special Mechanisms:

\begin{abstract}
Although Hezbollah, a non-State actor, cannot become a party to these human rights treaties, it remains subject to the demand of the international community, first expressed in the Universal Declaration of Human Rights, that every organ of society respect and promote human rights. The Security Council has long called upon various groups which Member States do not recognize as having the capacity to do so to formally assume international obligations to respect human rights. It is especially appropriate and feasible to call for an armed group to respect human rights norms when it "exercises significant control over territory and population and has an identifiable political structure". ${ }^{131}$
\end{abstract}

Calling for a group to respect human rights is one thing, engaging with the group over why it has not respected such human rights, or even assisting the group to come into compliance raises a whole new set of legitimacy problems. The issue is less whether the standards apply, but rather that there is a perceived sense of legitimization through the act of engagement. To the extent that the group is most probably proscribed under national law, or even targeted under international law, then association with or assistance to the group carries with it the risk of being considered to have aided or abetted terrorism. While governments have usually understood that the International Committee of the Red Cross have to engage such groups in a dialogue about the laws of war, human rights monitors have been wary of engagement, and humanitarian workers

\footnotetext{
${ }^{128}$ Footnote in the original reads: "SC Res. 1265 (1999), preamble; SC Res. 1193 (1998), paras. 12, 14; SC Res. 814 (1993), para. 13."

${ }^{129}$ UN Doc. E/CN.4/2006/53/Add.5, 27 March 2006 (footnote omitted) at paras. 25-27..

${ }^{130} \mathrm{Ibid}$., para. 85. See also the letter addressed directly to the LTTE concerning prevention of killings, investigation, and the application of the death penalty, 'Allegation letter sent 21 November 2005, UN Doc. E/CN.4/53/Add.1, 27 March 2006 , at p. 320. Note the 'Urgent appeal' sent to the Palestinian Authority regarding death sentences, on 28 February 2005, Ibid. at p. 321.

${ }^{131}$ Report of the Special Rapporteur on extrajudicial, summary or arbitrary executions, Philip Alston; the Special Rapporteur on the right of everyone to the enjoyment of the highest attainable standard of physical and mental health, Paul Hunt; the Representative of the Secretary-General on human rights of internally displaced persons, Walter Kälin; and the Special Rapporteur on adequate housing as a component of the right to an adequate standard of living, Miloon Kothari, UN Doc. $\mathrm{A} / \mathrm{HRC} / 2 / 7,2$ October 2006, at para. 19. Footnotes omitted.
} 
are becoming cautious regarding their dealings with such armed groups due to the risks of guilt by association in the 'war on terror'. ${ }^{132}$

Alston's report on Afghanistan illuminates the dilemma for human rights monitors. Having recalled the demand from some quarters for more pressure to be brought on the Government of Pakistan, he continues:

\begin{abstract}
Others argued that there was a need for international actors to engage directly with the Taliban to understand the rationales for its abusive tactics and to apply targeted pressure for change. Prominent elders in the South told me directly that the problem with visits by international envoys was that they only spoke to one side. An international military commander expressed surprise that I was not speaking with Taliban representatives. In general, when I conduct country visits and fact-finding missions, I speak with armed opposition groups, but I did not speak with any formal representatives of the Taliban or other armed groups during my visit. ${ }^{133}$ In retrospect, this was a mistake. Taking account of information provided by such sources would permit a more nuanced understanding of Taliban and other AGE [anti-government-element] strategies. While some of the explanations and justifications provided for engaging in abusive tactics would be self-serving and deceitful, there is no reason to assume that the Taliban could never be persuaded to modify its conduct in ways that would improve its respect for human rights. And purely humanitarian contacts have had a positive impact in the past. ${ }^{134}$
\end{abstract}

The distinction between the 'purely humanitarian' and the human rights approach is narrowing. Why should 'humanitarian' engagement over the treatment of detainees or access to food parcels be seen as radically different from human rights engagement over the treatment of women or extrajudicial execution? The assumption may be that such human rights topics suggest that the addressee is a state-like entity while humanitarian engagement suggests a rebel groups that has achieved a degree of control and organization. Moreover some may argue that the human rights norms are less universally accepted than the humanitarian law norms. Neither of these suggestions seems convincing. But as we have just seen the UN's Special Mechanisms consider it is 'especially appropriate and feasible' for the international community to apply human rights norms when the group has 'exercises significant control over territory and population and has an identifiable political structure'. It seems most likely that the Human Rights Council, through its special procedures and ad hoc fact finding missions will inevitably have to monitor both the behaviour of governments and those armed non-state actors they are fighting. To the extent that the Human Rights Council is not necessarily empowered to report generally on violations of international humanitarian law they will be forced to label the violations committed by armed non-state actors violations as violations of human rights. Furthermore the UN Human Rights Council's Special Mechanisms will be more and more likely to engage with these armed groups in order, not only to gather information about the situation, but also in order to attempt to get these actors to change their behaviour.

\footnotetext{
${ }^{132}$ K Thorne, 'Terrorist Lists and Humanitarian Assistance', vol. 37 Humanitarian Exchange (2007) 13.

133 'Initially, I assumed that security concerns, largely of the armed groups' own making, would make doing so impossible. I was also aware that various actors had reservations about the political implications of doing so. Ultimately, I felt I had no option but to abide by these reservations despite the fact that realistic opportunities were presented to me.' Footnote in the original.

${ }^{134}$ Report of the Special Rapporteur on extrajudicial, summary or arbitrary executions, Mission to Afghanistan, UN Doc. A/HRC/11/2/Add.4, 6 May 2009, para. 42.
} 


\section{B. UN Human Rights Field Officers}

UN human rights field operations in places such as Colombia and Nepal have for some time been grappling with how to report on abuses committed by the relevant armed non-state actors. So, for example, the reports of the field operation in Nepal have included special sections on incidents involving the Communist Party of Nepal (Maoist) (CPN-M) ${ }^{135}$ Often such field reports cannot be expressed in terms of violations of international humanitarian law, as they took place during the cease-fire, outside the context of an armed conflict.

The publication by a group of experts of 'The Guiding Principles for Human Rights Field Officers' has addressed the issue of reporting on and engaging with armed non-state actors. ${ }^{136}$

Guiding Principle 1: The law

International human rights law is the basis for the work of human rights field officers (HRFOs) and includes recognition of human rights for all persons, and the indivisibility of all rights, civil, cultural, economic, political and social. In armed conflicts HRFOs also apply international humanitarian law.

C. Human rights obligations: the state is the entity responsible for guaranteeing all rights, including through all its agents. In addition a growing consensus holds that some non-state actors, especially militias, paramilitary organisations, and even private, commercial enterprises including corporations may incur human rights responsibilities. Depending on the overall guidance, policy and strategy developed by the field operation's leadership, HRFOs may engage these entities in their work.

D. International humanitarian law: applies in situations of armed conflict, international and internal in different degrees, and includes protection of all persons not taking an active part in hostilities. It applies jointly with human rights law. It imposes obligations on all parties to the conflict, including non-state actors.

Guiding Principle 8: Partnership

Partnerships define the work of HRFOs. Without close cooperation, consultation and communication with international and national partners, HRFOs will never succeed. The best partnerships promote the primacy of local actors.

C. Partnership with whom: the range of partners is broad. The most obvious groups include: national state authorities (particularly those in the ministries responsible for justice, interior, foreign affairs, defence, women, children, health, education, land and development); national and international non-governmental organisations; national human rights institutions; non-state actors, including armed opposition groups (where present and permitted under the mission's mandate and policy).

These guidelines represent an important development in that first, the human rights responsibilities of armed non-state actors are recognized (at least according to a 'growing consensus'); and second, success for a human rights field operation is seen as dependent on local partnerships, and, in turn, this means partnering with armed opposition groups where 'permitted under the mission's mandate.' This is a neat way to square the legitimacy circle. UN

${ }^{135}$ See eg UN Doc. E/CN.4/2006/107 of 16 February 2006, paras. 45-58.

${ }^{136} \mathrm{http}: / / \mathrm{www}$.hrfoguidingprinciples.org available in English, French and Spanish. 
Engagement cannot be considered an unacceptable interference, or as bestowing legitimacy on the group, because the mission itself has been given the mandate to undertake this sort of engagement and move towards accountability from the armed group. ${ }^{137}$

\section{The Work of the Security Council and the Special Representative on Children in Armed Conflict}

The UN's work on children in armed conflict has led to an innovative approach which details violations by non-state actors. Reports by the UN Secretary-General to the Security Council on certain country situations now list the non-state actors concerned and whether or not they are involved in any of six categories of 'grave violations':

(a) Killing or maiming of children;

(b) Recruiting or using child soldiers;

(c) Attacks against schools or hospitals;

(d) Rape or other grave sexual violence against children;

(e) Abduction of children;

(f) Denial of humanitarian access for children

The UN Secretary-General's initial report explains that these violations are based on international norms, and commitments that have been made by the parties to the conflict, as well as national laws and peace agreements. ${ }^{138}$ Subsequent reports on various country situations have detailed the 'grave violations of children's rights' committed by the non-state actors concerned. ${ }^{139}$ These reports dedicate as much if not more space to the violations committed by the non-state actors as they do to addressing the states concerned. Although the focus started with recruitment, the Security Council has now requested the Secretary-General to include in his reports 'those parties to armed conflict that engage, in contravention of applicable international law, in patterns of killing and maiming of children and/or rape and other sexual violence against children, in situations of armed conflict'. ${ }^{140}$

\footnotetext{
${ }^{137}$ The assumption here might be that either the host state has consented to the mission and its terms or that the Security Council has authorized such activity under Chapter VII and so no question of Article 2(7) of the UN Charter arises. The annotations to the Guidelines reference the following pieces of writing: 'Maria Stavropoulou, 'Protection: The Office of the United Nations High Commissioner for Refugees Experience', and Alain Aeschlimann, 'Protection: The International Committee of the Red Cross Experience', both in Michael O"Flaherty (ed.), The Human Rights Field Operation: Law, Theory and Practice, Hampshire: Ashgate Publishing Limited, 2007.

${ }^{138}$ UN Doc. S/2005/72. ; for a recent look at the legal aspects of these categories see The Six Grave Violations Against Children During Armed Conflict: The Legal Foundation, Woking Paper No. 1, Office of the Special Representative of the SecretaryGeneral for Children and Armed Conflict (2009).

139 The most recent SG report is S/2009/158. Relevant country reports are: Democratic Republic of the Congo, S/2006/389, Sudan, S/2006/662; Côte d'Ivoire, S/2006/835; Burundi, S/2006/851; Sri Lanka, S/2007/758; Burundi, S/2007/68; Myanmar, S/2007/666; Côte d'Ivoire S/2007/515; Sudan, S/2007/520; Chad, S/2007/400; Democratic Republic of the Congo, S/2007/391; Uganda, S/2007/260; Somalia, S/2007/259; Nepal, S/2006/1007; Sri Lanka, S/2006/1006; Côte d'Ivoire, S/2006/835; Nepal, S/2008/259; Philippines, S/2008/272; Somalia, S/2008/352; Chad, S/2008/532; Democratic Republic of the Congo, S/2008/693; Afghanistan, S/2008/695; Central African Republic, S/2009/66; Sudan, see S/2009/84; Sri Lanka, S/2009/325. Myanmar, S/2009/278, Sudan, S/2009/84; Central African Republic, S/2009/66.

${ }^{140}$ SC Res 1882 of 4 August 2009.
} 
The mechanism vis-à-vis the non-state actor works not only through naming and shaming but by encouraging the non-state actor to submit an 'action plan' to the Security Council, in this way the group can be removed from the list of violators. One non-state armed group that has supplied such an action plan and claimed to no longer be a violator is the Forces Nouvelles (FAFN) in Cote d'Ivoire, and they were eventually delisted by the Security Council in $2008 .{ }^{141}$ The Security Council also has in mind that it could adopt 'country-specific resolutions, targeted and graduated measures, such as, inter alia, a ban on the export and supply of small arms and light weapons and of other military equipment and on military assistance, against parties to situations of armed conflict which are on the Security Council's agenda and are in violation of applicable international law relating to the rights and protection of children in armed conflict. ${ }^{, 142}$

While the focus seems to be on violations of applicable law in situations of armed conflict the work is not restricted to the applications of international humanitarian law. The question of the criteria for a group to be considered a party to an armed conflict is not carefully examined. The universal standard seems to apply outside the strict framework of international humanitarian law. These reports are complemented by the work of the Special Representative of the SecretaryGeneral, whose work not only feeds into the reports to the Security Council, but also relies on country visits, engaging with non-state actors and facilitating commitments by those armed groups. ${ }^{143}$ The Special Representative's reports and activities have covered groups which were not recognized as parties to a conflict by the states concerned. ${ }^{144}$ Furthermore the Special Representative has developed a methodology based on commitments by the armed non-state actor rather than a strict application of humanitarian law to a party to a conflict. ${ }^{145}$ For these reasons it seems more appropriate to consider this question as a matter of international human rights standards rather than international humanitarian law and the obligations exist whether or not there is an armed conflict. This technique of applying universal standards to armed non-state actors and then engaging with them to monitor and encourage consent has been developed by various non-governmental organizations including, in particular, Geneva Call.

\section{Non-Governmental Approaches and the Example of Geneva Call}

Engagement with armed groups is not limited to UN human rights mechanisms. Nongovernmental organizations such as Human Rights Watch increasingly report on human rights abuses committed by armed non-state actors. ${ }^{146}$ So far its reports on Hamas and Fatah emphasize the commitment of the Palestinian Authority to human rights and the fact that these groups are

\footnotetext{
${ }^{141}$ See UN Doc. S/AC.51/2008/5, 1 February 2008 for more detail.

${ }^{142}$ Security Council Resolution 1612, para. 9.

${ }^{143}$ See eg the report A/63/227 of 6 August 2008; see further A. Clapham, Human Rights Obligations of Non-State Actors (Oxford: Oxford University Press, 2006) at 289-90.

${ }^{144}$ Discussed in 'Human rights obligations of non-state actors in conflict situations' supra at 512-3.

${ }^{145}$ See the discussion in Human Rights Obligations of Non-State Actors (supra) at 289-291.

${ }^{146}$ Human Rights Watch: "You'll Learn not to Cry": Child Combatants in Colombia (2003); No Exit: Human Rights Abuses Inside the MKO Camps (2005); A Face and a Name: Civilian Victims of Insurgent Groups in Iraq(2005); A Question of Security: Violence against Palestinian Women and Girls, (2006); Renewed Crisis in North Kivu (2007); "All the Men Have Gone": War Crimes in Kenya's Mt. Elgon Conflict (2008); Internal Fight: Palestinian Abuses in Gaza and the West Bank (2008); Trapped and Mistreated: LTTE Abuses against Civilians in the Vanni (2008); War on the Displaced: Sri Lankan Army and LTTE Abuses against Civilians in the Vanni, 2009; Pursuit of Power: Political Violence and Repression in Burundi (2009); Under Cover of War: Hamas Political Violence in Gaza (2009); The Christmas Massacres: LRA attacks on Civilians in Northern Congo (2009); Paramilitaries' Heirs: The New Face of Violence in Colombia (2010).
} 
seen to be in control of territory. ${ }^{147}$ In other situations human rights law is transposed from the state-based treaty provisions in ways that allude to customary international law or, in one case, where a non-state actor's justice system was found wanting the report stated: 'The fairness of any justice system should be tested against international human rights law criteria that include independence, impartiality, and competency of judges, presumption of innocence, right to legal counsel and adequate time for preparation of defense, and the right to appeal. ${ }^{148}$ We see here that the apparent doctrinal problem of applying human rights law to armed non-state actors has been overcome through simply invoking universally accepted values: fairness, independence, impartiality, competence, the presumption of innocence, and the right to defend oneself. Amnesty International's reports similarly address their concerns to the armed non-state actors in terms which go beyond the strict obligations found under the laws of war. ${ }^{149}$ Of course the fact that these two organizations are holding armed non-state actors to human rights standards does not generate the obligations themselves. But the reports need to be seen against the general acceptance, not only at the level of the UN Human Rights Council, but also through the resolutions and activity of the Security Council, that armed groups should be accountable under the international rule of law.

Let us now consider the approach of a third organization, Geneva Call. The International Campaign to Ban Landmines, having recognized the limits of the Ottawa Treaty to address the possession and use of landmines by non-state actors, set up their own working group which led eventually to the establishment of the NGO Geneva Call. ${ }^{150}$ The organization Geneva Call has engaged armed groups in 'Deeds of Commitment' regarding a 'total ban on anti-personnel mines and for cooperation in mine action'. Having negotiated the signature of the Deed, Geneva Call receives the armed non-state actors' regular reports, monitors compliance with the Deed and helps arrange mine action including demining and destruction of stocks. It is worth inquiring at this point what might be the incentives for such a non-state actor to bind themselves to such a Deed.

First, rebel groups realize the advantages of being seen to abide by international norms in the context of moves towards peace negotiations; second, it is much easier to criticize governments and their armed forces for violating humanitarian norms if the group has policies in place to avoid and punish similar violations; third, factions may be able to distinguish themselves from other armed groups and thus 'get ahead' in terms of dialogue with the government or other actors; lastly in some circumstances entering into such commitments will facilitate access to assistance from the international community in the form of mine clearance.

\footnotetext{
${ }^{147}$ See previous footnote.

148 "Being Neutral is Our Biggest Crime": Government, Vigilante, and Naxalite Abuses in India's Chhattisgarh State (2008) at 98. See further S. Sivakumaran, "Courts of Armed Opposition: Fair Trials or Summary Justice?", vol. 7 JICJ (2009) 489-513.

${ }^{149}$ See "Israel And The Occupied Territories And The Palestinian Authority: Without distinction - attacks on civilians by Palestinian armed groups, AI Index MDE 02/003/2002; Algeria: Steps towards change or empty promises?, MDE 28/005/2003; DRC: On the precipice: the deepening human rights and humanitarian crisis in Ituri', AFR 62/006/2003; DRC: Addressing the present and building a future, AFR 62/050/2003; Haiti: Abuse of human rights: political violence as the 200th anniversary of independence approaches, AMR 36/007/2003; Iraq: In cold blood: abuses by armed groups, AI Index MDE 14/009/2005; Democratic Republic of Congo North Kivu: No End to War on Women and Children, AI Index AFR 62/005/2008; Carnage and Despair: Iraq five years on AI Index: MDE 14/001/2008; Russian Federation; Rule without law: Human rights violations in the North Caucasus, AI Index EUR 46/012/2009.

${ }^{150}$ See Margaret Busé, 'Non-State Actors and their Significance' 5.3 Journal of Mine Action (2001) online. See also S. Shackle, 'Landmine ban failing' New Statesman 11 December 2008.
} 
Such explicit recognition of specific obligations by the groups themselves helps to transform the debate about the human rights obligations of non-state actors. If armed groups are prepared to take on such obligations, arguments about their non-applicability under international law lose much of their force. States may fear the legitimacy that such commitments seem to imply, and international lawyers may choose to accord them no value, but from a victim's perspective such commitments may indeed be worth more than the paper they are written on.

The extension beyond the issue of anti-personnel mines into human rights obligations for non-state actors is foreseen in the Statute of Geneva Call, which states that its aim is to be 'dedicated to engaging armed non-State actors to adhere to a ban on landmines and to respect humanitarian and human rights norms, in particular, through the signing of deeds of commitment to a total ban on:- the use of anti-personnel mines; - the enrolment and/or the use of child soldiers; - the practice of torture and other cruel, inhuman or degrading treatment'. ${ }^{151}$ At the time of writing it looks likely that a similar Deed of Commitment will be developed to address the issue of the participation of children in armed conflict.

\section{INTERNATIONAL CRIMINAL LAW}

The development of international criminal law so as to apply to individuals fighting with nonstate armed groups has been rapid and sophisticated. The International Criminal Tribunals for the former Yugoslavia and Rwanda have developed not only a complex catalogue of crimes but also rules concerning superior responsibility and joint criminal enterprise. Furthermore individual criminal responsibility clearly applies outside the context of armed conflicts to situations which constitute crimes against humanity or genocide. And, in some cases, international criminal law has been used to prosecute the members of armed non-state groups for treaty crimes such as torture and hostage-taking. ${ }^{152}$ The list is not closed and one should mention the crimes of piracy, forced labour and enforced disappearance as clearly relevant in this regard.

A cursory glance at the work of the International Criminal Court reveals that it will be individuals from armed non-state actors who are likely to make up the bulk of the defendants there. Three states have all referred their own situations to the Court, in all three cases: Uganda, Central African Republic and the Democratic Republic of the Congo, the Government is cooperating in order to see non-state actors tried before the Court. All the detainees in custody at the time of writing are individuals from armed non-state actors. Governments will not lightly hand over their own forces for international prosecution.

As the focus turns to individuals wanted for the most serious crimes an inevitable prosecutorial selection will result in leaders from armed groups being targeted for prosecution. In turn this begs the question: in what sort of leader will there be liable for prosecution for international crimes flowing from the rules concerning command responsibility? We now turn to examine this question in some detail.

\footnotetext{
151 Article 3.

${ }^{152}$ See eg the Zardad trial in 2004, discussed in Human Rights Obligations of Non-State Actors at 343-4.
} 


\section{A. International Crimes and Superior Responsibility by Responsible Commanders from Armed Non-State Actors}

The application of the doctrine of international individual criminal superior responsibility for commanders to internal armed conflicts was explicitly challenged before the International Criminal Tribunal for the former Yugoslavia. ${ }^{153}$ The Appeals Chamber was clear:

Referring to the criteria for determining whether there was an "armed conflict not of an international character" within the meaning of that provision, the ICRC Commentary spoke, authoritatively, of a revolting party possessing "an organized military force, an authority responsible for its acts, acting within a determinate territory and having the means of respecting and ensuring respect for the" convention. Article 1(1) of Protocol II Additional to the Geneva Conventions likewise spoke of a Contracting Party's “armed forces and dissident armed forces or other organized armed groups which, under responsible command, exercise such control over a part of its territory as to enable them to carry out sustained and concerted military operations ...".

Thus, whether Article 3 of the Statute is referring to war crimes committed in the course of international armed conflict or to war crimes committed in the course of internal armed conflict under Article 3 common to the Geneva Conventions, it assumes that there is an organized military force. It is evident that there cannot be an organized military force save on the basis of responsible command. It is also reasonable to hold that it is responsible command which leads to command responsibility. Command responsibility is the most effective method by which international criminal law can enforce responsible command.

It is true that, domestically, most States have not legislated for command responsibility to be the counterpart of responsible command in internal conflict. This, however, does not affect the fact that, at the international level, they have accepted that, as a matter of customary international law, relevant aspects of international law (including the concept of command responsibility) govern the conduct of an internal armed conflict, though of course not all aspects of international law apply. The relevant aspects of international law unquestionably regard a military force engaged in an internal armed conflict as organized and therefore as being under responsible command. In the absence of anything to the contrary, it is the task of a court to interpret the underlying State practice and opinio juris (relating to the requirement that such a military force be organized) as bearing its normal meaning that military organization implies responsible command and that responsible command in turn implies command responsibility.

In short, wherever customary international law recognizes that a war crime can be committed by a member of an organised military force, it also recognizes that a commander can be penally sanctioned if he knew or had reason to know that his subordinate was about to commit a prohibited act or had done so and the commander failed to take the necessary and reasonable measures to prevent such an act or to punish the subordinate. Customary international law recognizes that some war crimes can be committed by a member of an organised military force in the course of an internal armed conflict; it therefore also recognizes that there can be command responsibility in respect of such crimes. ${ }^{154}$

In short, once the armed non-state group satisfies the conditions to trigger the application of humanitarian law due to the existence of an armed conflict, there will be, almost by definition, a responsible command and commanders. Such commanders can be held criminally responsible for war crimes committed by their subordinates under the conditions set out above and may in some circumstances be responsible for failing to prevent such crimes. ${ }^{155}$

\footnotetext{
${ }^{153}$ See Prosecutor v Enver Hadzihasanovic, Mehmed Alagic and Amir Kubura, Decision on Interlocutory Appeal Challenging Jurisdiction in Relation to Command Responsibility, Case IT-01-47-AR72, Decision of 16 July 2003.

${ }^{154}$ Ibid. at paras. $15-18$.

${ }^{155}$ For more detail see A. Cassese, International Criminal Law, 2nd edn, Oxford: Oxford University Press (2008) at 243ff.
} 
Not much has been written about developing the criteria so that the particular situation of rebel commanders is taken into account; some of the traditional command responsibility tests used with regard to the state party may not be easily applicable. There is some consideration of this issue, however, by the Special Court for Sierra Leone where the Chamber recalled that the effective control test might be more loosely defined so that 'the power of the superior to issue orders is crucial, although these orders may be criminal in nature. Similarly, the superior must be capable of taking disciplinary action, even though the measures taken may be more brutal and arbitrarily used.' ${ }^{156}$ The Chamber stated: 'The less developed the structure, the more important it becomes to focus on the nature of the superior's authority rather than his or her formal designation. ${ }^{157}$ The Court then goes on to list 'indicia' they consider useful in this regard including whether the superior:

exercised control over the fate of vulnerable persons such as women and children; the superior had independent access to and/or control of the means to wage war, including arms and ammunition and communications equipment; ... the superior had the capacity to intimidate subordinates into compliance and was willing to do so; the superior was protected by personal security guards, loyal to him or her, akin to a praetorian guard; the superior fuels or represents the ideology of the movement to which the subordinates adhere; and the superior interacts with external bodies or individuals on behalf of the group. ${ }^{158}$

In terms of engagement and ownership these indicia are relevant in any negotiation. It must be said, that, if being seen to be the person engaging opens the negotiator up to later claims of command responsibility, we need to consider the policy implications for any attempt to engage with certain individuals to increase the ownership of these norms. Perhaps there needs to be a discussion on how to separate the roles of negotiator from superior. The process of negotiating the norm should lead to a sense of ownership by the group, rather than being seen as potential evidence in a war crimes trial.

\section{B. The Alien Tort Statute}

We have seen the impact of international tribunals that prosecute individuals. But what of the obligations of the armed non-state actor itself? Is it bound by international criminal law? And if so how? It is worth looking at these questions in a little detail as it is suggested there are some quite unusual practical applications. Although the group as such cannot be tried before the International Criminal Court, national jurisdictions may have to consider the responsibility of the group under these international criminal norms. In this regard it is worth looking in particular at developments surrounding the US Alien Tort Statute.

As its name implies the Alien Tort Statute allows for tort, not criminal, cases to be brought before the US Federal Courts. Nevertheless the suits have developed around international criminal law obligations and the normative framework deployed is international criminal law, not only with regard to the substantive obligations but also with regard to secondary liability, for example for complicity in violations of the norms. It makes sense in the present

\footnotetext{
${ }^{156}$ Prosecutor v Brima et al, SCSL-04-16-T, 20 June 2007, at para. 789.

${ }^{157}$ Ibid. at para. 787.

${ }^{158}$ Ibid. at para. 788 .
} 
context therefore to consider this as a consequence of the development of international criminal law rather than under another heading. ${ }^{159}$

Let us consider a complaint brought against the Chiquita company for complicity in crimes against humanity, war crimes and torture allegedly committed with a paramilitary organization (the United Self-Defence Committees of Columbia (AUC). This civil suit under the Alien Tort Statute depends on proving that the protection money offered by Chiquita facilitated international crimes committed by the group (rather than showing that the crimes were committed by any one or more individuals). ${ }^{160}$ Other suits have been brought against Chiquita for contributing to the deaths of individuals at the hands of the rebel group the Revolutionary Armed Forces of Columbia (FARC). ${ }^{161}$ Whether or not these suits are successful, the point remains that there will be situations where the victims of international crimes committed by armed groups may need to rely on the notion that an armed group can commit violations of international criminal law as a group (even if this is only as a way to recover reparation from a corporate accomplice).

A further example of a third party being accused of complicity in an international crime being committed by an armed opposition group is the suit brought against Libya for complicity in the international crimes committed by the Provisional IRA (PIRA). The suit, brought by the victims of the bombings, alleges inter alia in Count IX that the:

313. PIRA bombings utilized Semtex as the primary explosive ingredient against the Alien Plaintiffs and the unarmed British population constitute crimes against humanity in violation of the law of nations....

319. Throughout the 1980s and 1990s, this campaign by the PIRA was widespread and systematic against the civilian population.

320 Libya, through its officials, employees, and agents including but not limited to defendants Qadhafi, Senoussi, Kusa, Ashour, and Bazelya, knowingly, intentionally and directly aided and abetted, intentionally facilitated, and/or recklessly disregarded crimes against humanity in violation of the law of nations. ${ }^{162}$

The complaint goes on to allege the supply of arms and ammunition, training, training facilities, and a base of operations within Libya. And the complaint also alleges that Libya knew that its provisions of arms etc would 'be used to carry out crimes against humanity against the civilian populations in Great Britain and Northern Ireland by the PIRA.' ${ }^{163}$ An essential link in the legal argumentation is that the PIRA as such committed international crimes. Knowingly assisting such a group then becomes a violation of international law.

The most recent decisions of the US courts in this area has set down some parameters for what sort of violations by non-state armed groups might fall under this Statute, and what sort of knowledge or purpose will be necessary to find an organization liable for complicity in a

\footnotetext{
159 'Is this ATS law 'international criminal law'? Not in the sense of international criminal law as established by international tribunals. But it is a form of international criminal law as far as US courts are concerned, even if others in the world think that it perhaps deserves its own special appellation - 'ATS-international law', maybe - to distinguish that parochialism from the genuinely universal 'real thing'. K. Anderson, 'The Rise of International Criminal Law: Intended and Unintended Consequences', vol. 20 EJIL (2009) 331-58, at 351.

${ }^{160}$ John Doe et al v. Chiquita Brands International, United States District Court, District of New Jersey, filed 18 July 2007.

161 'Families Sue Chiquita in Deaths of 5 Men', New York Times, 17 March 2008.

${ }^{162}$ Class Action McDonald et al v The Socialist People's Libyan Arab Jamahiriya, US District Court for the District of Columbia, filed 21 April 2006.

${ }^{163}$ Ibid. at para. 322
} 
violation of the law of nations. First, it is now becoming clear that the US Courts will not demand a link to state action for the following violations of international law: war crimes, genocide, and crimes against humanity. A recent Court of Appeals decision reviewed the caselaw and recalled the jurisprudence which sees violations of Common Article 3 to the Geneva Conventions as war crimes and mentions that: 'This standard applies to "all 'parties' to a conflict ... which includes insurgent military groups." 164 The same Court restricted liability for conspiracy to the crimes of genocide and aggression and then concluded that a secondary perpetrator accused of aiding and abetting would have to act not just with knowledge of their contribution to the violation but also with the purpose of violating international law. The Court, even though it was acting in a civil case said it drew this rule from the rule found in the Statute of the International Criminal Court. ${ }^{165}$ The case turned on whether the Canadian oil company Talisman acted with such a purpose in its assistance to the Sudanese Government in the violation of international humanitarian law. Given that the US Courts accept that the same rule applies to insurgent groups one can see that these Courts would also have potential jurisdiction over a company that assisted a non-state armed group to violate international criminal law. In the words of the Court:

True, intent must often be demonstrated by the circumstances, and there may well be an ATS case in which a genuine issue of fact as to a defendant's intent to aid and abet the principal could be inferred; but in this case, there were insufficient facts or circumstances suggesting that Talisman acted with the purpose to advance violations of international humanitarian law. ${ }^{166}$

Inferred intent for companies assisting a non-state actor could therefore lead to compensation awarded against a company for complicity in war crimes. This suggests that companies are significant stakeholders in ensuring the absence of violations of international law by armed nonstate actors. As they are inevitably engaged in their own negotiations with these armed groups their role in ensuring the adoption of the norms should be carefully considered.

\footnotetext{
${ }^{164}$ The Presbyterian Church of Sudan et al v Talisman Energy et al, US Ct of Appeals $2^{\text {nd }}$ Cir., Docket No. 07-0016-cv, Decision of 2 October 2009 at page 35 of the unpublished Decision.

${ }^{165}$ For references to alternative readings of Article 25(3)(c) of the ICC Statute see 'Extending International Criminal law' supra at 912.

${ }^{166}$ Presbyterian Church of Sudan (supra) at 55.
} 


\section{IS ENGAGEMENT WITH NON-STATE ACTORS A VIOLATION OF THE NON-INTERFERENCE RULE IN INTERNATIONAL LAW?}

The principle of non-interference in internal affairs is sometimes raised with the suggestion that engagement with certain armed non-state actors is in violation of this principle of international law. In order to determine when, if at all, this might be the case we need to break down the principle into the following components; what represents interference? What are internal affairs? And who is subject to this obligation?

\section{A. Interference}

The principle (as enshrined in Article 2(7) of the UN Charter) was contested from the early days of the United Nations. ${ }^{167}$ In 1955, the Indian delegate to the United Nations General Assembly stated in the context of a debate over South Africa that 'if discussion in the United Nations were intervention, it would be governed by Article 2(7) and this would reduce the Charter to an absurdity'. ${ }^{168}$ It is perhaps safe to assume that, today, inclusion or discussion of an item on the agenda of the General Assembly (or its subsidiary bodies) cannot be considered an intervention, ${ }^{169}$ and that even when the outcome rises to the level of a recommendation with regard to a violation of international law (whether it be humanitarian, human rights or criminal aw), this can hardly now be seen as concerning 'matters which are essentially within the domestic jurisdiction of any State'. ${ }^{170}$

The crucial Article in the UN Charter which covers intervention by States is Article 2(4) which prohibits Member States from using force 'against the territorial integrity or political independence of any State, or in any other manner inconsistent with the Purposes of the United Nations.' The interpretation of this prohibition and the prohibition on other forms of intervention by States was outlined in the General Assembly's Declaration of Principles of International Law concerning Friendly Relations and Cooperation between States adopted by consensus on 24 October 1970, on the 25th birthday of the United Nations. Two of the relevant paragraphs read as follows:

No State or group of States has the right to intervene, directly or indirectly, for any reason whatsoever, in the internal or external affairs of another State. Consequently, armed intervention and all other forms of interference or attempted threats against the personality of the State or against its political, economic and cultural elements, are in violation of international law.

\footnotetext{
${ }^{167}$ Art 2(7) 'Nothing contained in the present Charter shall authorize the United Nations to intervene in matters which are essentially within the domestic jurisdiction of any State or shall require the members to submit such matters to settlement under the present Charter; but this principle shall not prejudice the application of enforcement measures under Chapter VII.'

${ }^{168}$ GAOR (1955), Plenary Meetings, 530th meeting, para. 139, p. 190. Cited in A.A.C. Trindade, 'The Domestic Jurisdiction of States in the Practice of the United Nations and Regional Organisations', International and Comparative Law Quarterly, vol. 25 (October 1976), pp. 715-765, at p. 731.

${ }^{169}$ See G. Nolte, 'Article 2(7)', in B. Simma (ed.), The Charter of the United Nations: A Commentary (Oxford: Oxford University Press, 2002) 2nd ed, pp. 148-171, at p. 155.

${ }^{170}$ See $\backslash$ Article 2(7) supra.
} 
No State may use or encourage the use of economic, political or any other type of measures to coerce another State in order to obtain from it the subordination of the exercise of its sovereign rights and to secure from it advantages of any kind. Also, no State shall organize, assist, foment, finance, incite or tolerate subversive, terrorist or armed activities directed towards the violent overthrow of the régime of another State, or interfere in civil strife in another State.

It seems that forms of interference that can not be categorized as armed intervention are prohibited to the extent that they threaten the personality or other elements of the target State. It is the effect on the target State which is crucial rather than the sort of behaviour exhibited by the interfering State. Our interest here is the legality of engagement, or expressions of encouragement to respect humanitarian norms, directed towards rebel groups. A statement could only constitute a violation of international law if it was part of an act which had particular effects in the target State. Georges Abi-Saab suggests that an act could violate the principle of noninterference in two different categories of cases. ${ }^{171}$ First, if 'it carries or constitutes in itself a negation of the sovereignty of the other State'; this would be so for example 'where a State exercises acts of public authority or enforcement such as the arrest of certain persons on the territory of another State without its consent, as if the latter did not exist as a sovereign State. ${ }^{172}$ Secondly, he suggests that it would be illegal for a State to act in a situation where that act has the effect of 'bending the will of the other State in order to force it to act in a certain manner against its will'.

\section{B. Internal Affairs}

The Institute of International Law has addressed the question of what can be considered a question of internal affairs or domaine reservé. The Institute's 1989 Resolution stated in its Article 2 that 'A State acting in breach of its obligations in the sphere of human rights cannot evade its international responsibility by claiming that such matters are essentially within its domestic jurisdiction.' Article 3 reads: 'Diplomatic representations as well as purely verbal expressions of concern or disapproval regarding any violations of human rights are lawful in all circumstances. ${ }^{173}$ It is therefore hard to see how any expressions of concern over humanitarian norms could fit within any prohibited categories of interference. ${ }^{174}$ Even if the subject fell in an area where states retain some discretion under international human rights law (say whether to become a party to the optional protocol on children in armed conflict) then an appeal or

\footnotetext{
171 'Some Thoughts on the Principle of Non-Intervention' in K. Wellens (ed.) International Law: Theory and Practice, (1998) 225-235, at 228 .

${ }^{172}$ Ibid. The other example he gives in this context may be "the "premature recognition" of a secessionist State, which by definition, signifies the negation of the sovereignty of the State on that part of the territory that attempts to secede'. This is a reference to the recognition by the United States of the Panamanian secession from Colombia in 1903. See G. Abi-Saab Cours Général de Droit International Public, Recueil des cours, volume 207 (1996) pp. 380-389 at 382.

${ }^{173}$ Adopted 13 September 1989, with no negative votes, Session of Saint-Jacques-de-Compostelle Resolution on 'The protection of human rights and the principle of non-intervention in internal affairs of states.' For Resolutions on the domaine réservé see the resolutions of 29 April 1954 at the Session of Aix-en-Provence and the Resolution of 22 August from the Oslo Session. Article 1 of the Aix-en-Provence Resolution reads: 'Le domaine réservé est celui des activités étatiques où la compétence de l'Etat n'est pas liées par le droit international. L'étendue de ce domaine dépend du droit international et varie suivant son développement.'

${ }^{174}$ See the recent statement by the European Union which explicitly states that compliance by non-state actors with IHL is a matter of international concern (ie not a matter considered exclusively one of internal affairs); Updated European Union Guidelines on promoting compliance with international humanitarian law (IHL) (2009/C 303/06) 15 December 2009, 'States are obliged to comply with the rules of IHL to which they are bound by treaty or which form part of customary international law. They may also apply to non-State actors. Such compliance is a matter of international concern.' At para. 5.
} 
expression of concern could not on its own be described as amounting to an act which has the effect of bending the will of a State and coercing it to act. To constitute an unlawful interference the concern would have to be coupled with some sort of sanctions capable of forcing a State to abandon its political, economic or cultural elements. ${ }^{175}$

\section{Who has the Obligation not to Interfere?}

So interference needs to rise to the level of coercion to violate the principle of non-interference as understood from the Friendly relations Declaration of 1970. Moreover the notion of internal affairs can not be used to fend off discussion about human rights obligations. Whether or not the non-intervention rule creates obligations for non-state actors has not been subject to much discussion. Where the question has been considered it would seem that the rule applies to intergovernmental organizations and states but cannot be applied to non-governmental organizations or individuals acting on their own without state complicity. According to the entry on 'Intervention' in the Max Planck Encyclopedia of Public International Law: 'The principle of non-intervention can not only be violated by a single State but also by a group of States or an international organization. Private persons, institutions or multinational companies cannot violate it through their behaviour. ${ }^{176}$

\section{NEW DIRECTIONS FOR ENGAGEMENT AND OWNERSHIP}

\section{A. Treaty Law}

As we have seen the treaty law situation is unsatisfactory, in all branches of international law the treaties leave the nature of the obligations addressed to the armed non-state armed group ambiguous. International humanitarian law is addressed to 'each Party to the conflict' and yet the thresholds for being considered a non-state 'party', or for the violence to be considered a 'conflict', are demanding. Moreover not all humanitarian law treaties are clear enough on whether they bind armed non-state actors: for example we saw how the 1999 Hague Protocol II is addressed to the State Parties to the treaty rather than the 'parties to the conflict' and we are asked to apply common sense as to which articles should appropriately apply to the non-state actor. Even when the articles of such international humanitarian law treaties are applied in a

\footnotetext{
175 Other relevant General Assembly Resolutions include, A/RES/2131 (XX) and A/RES/36/103. In Nicaragua v United States (supra) the International Court of Justice considered the cessation of economic aid in April 1981 to Nicaragua from the United States, the $90 \%$ reduction in the sugar quota for United States imports from Nicaragua in 1981, and the trade embargo adopted on May 1985. The Court rejected the argument that cumulatively these actions resulted in a systematic violation of the principle of non-intervention. At paras. 244 and 245. Of course the Court was not concerned whether any of these actions might have violated treaty obligations under economic instruments. The focus was on the question of intervention and the facts of the case: 'At this point, the Court has merely to say that it is unable to regard such action on the economic plane as is here complained of as a breach of the customary-law principle of non-intervention.' At para. 245.

${ }^{176}$ P. Kunig, 'Intervention, Prohibition of' Max Planck Encyclopaedia of Public International Law (Heidelberg: Oxford University Press, 2009) available at www.mpepil.com, at para.8.
} 
court of law against an individual the judges seem to feel that it makes more sense to rely on the customary nature of the obligations.

The following proposals might be ripe for discussion:

1. It has been suggested that representatives from armed non-state armed groups should be implicated and involved in any revision of international humanitarian law involving treaty drafting; this would not only increase the sense of ownership over the eventual norms, but also shape the norms in ways that made them relevant and practical. ${ }^{177}$ The problem of course is that some governments would object that such participation would lend legitimacy to the groups and would elevate criminals to the status of law-makers in their own interests. Here we face a fundamental problem which goes to the heart of the future effectiveness of international humanitarian law. For some, such as Sassòli, the armed non-state actor is not be seen as a collection of criminals but rather as party to an armed conflict, and the 'essence' of international humanitarian law is that it 'has to be applied by the parties and with the parties and it has to be based on an understanding of the problems, the dilemmas and the aspirations of the parties to armed conflicts'. ${ }^{178}$ In the current climate there may be considerable resistance to full representation in any treaty drafting process, but the point remains a good one, and we might consider ways of having a 'rebel point of view' included in treaty discussions, even if active armed non-state actors are not actually invited to participate fully in the treaty drafting procedures.

2. Human rights law is just as unsatisfactory with deliberate distance being built in between the norm and the addressees. We saw above that a number of techniques to create this distance have emerged. The use of 'should' instead of 'shall' to create an imperfect obligation, the focus on state repression rather than duties for the groups themselves, and an injunction on states to prohibit certain behaviour while simultaneously cataloguing obligations for the armed groups themselves. It is suggested that future human rights instruments should (shall/must?) avoid weakening the norms addressed to armed non-state actors. Human rights instruments must avoid descending into an apparent subjunctive mood and retain the indicative mood (so far reserved for state actors in this context). If international humanitarian law can retain the indicative 'shall' when addressing armed non-state actors so too can human rights texts. In this area, the legal convention that 'should' implies a less binding and less immediate obligation than 'shall', needs to be reconsidered. The New Fowler's Modern English provides classic examples of the use of should, as in 'small men shouldn't wear beards' (Kingsley Amis 1988). ${ }^{179}$ To address armed non-state actors with a 'should' is increasingly absurd. We have seen how there will inevitably be differences in the scope of obligation between states and nonstate actors, notably with regard to fair trial guarantees, but the case for differences in the degree of obligation to be deliberately inserted into treaties is rather weak and does nothing to protect the victims of human rights abuses. Human rights treaties need to address armed non-state actors directly and not confuse the injunction by phrasing

${ }^{177}$ See Sassòli 'The Implementation of Humanitarian Law' (supra) at 64.

178 Ibid.

${ }^{179}$ Oxford, Oxford University Press, $3^{\text {rd }}$ edn, 1998 at 711. 
demands as wishes. Let us abandon the should/shall distinction for state and nonstate actors.

Let us also think about developing the obligations on the non-state actors themselves in ways that are tailored to better ownership by the groups themselves. The long catalogue of obligations particularly addressed to armed groups in the African Union Convention represents a start. Future human rights treaties can afford to be more explicit on what exactly is required from non-state actors.

\section{B. Customary International Law}

We have seen that there is no shortage of lists of customary rules applicable to parties to armed conflicts. We have referred to the ICRC Study, the catalogue from the Darfur Commission, and the Statute of the International Criminal Court. While some caution has been noted with regard to transposing customary state obligations onto non-state actors, without thinking too hard about the logic of the differences between a rebel encampment and a modern metropolis, in general it is accepted that armed non-state actors can be the bearers of such obligations. The problem comes when one tries to apply the traditional thresholds in order to see whether the actor is a party to a conflict under international humanitarian law. In such cases governments have proven reluctant to admit that they are fighting a party to an armed conflict, preferring instead to refer to the actors as terrorists, criminals or 'illegal armed groups'. ${ }^{180}$ As long as governments remain content to allow other governments to self-determine the existence of an opposing party to an armed conflict, the application of customary international law to armed non-state actors will remain problematic.

1. The suggestion that customary norms should be determined in part through accumulating, or taking into consideration the practice of the armed non-state actors themselves needs to be properly debated. While the attraction of including such practice in order to generate a greater sense of ownership for the non-state actors themselves seems obvious, such a move would transform international law from a legal regime where the law-making authority resides with states, into a more descriptive normative framework where the law reflects existing cannons of behaviour by all concerned, rather than generating injunctions for non-state actors. As with the suggestion above on treaty-making, it may make sense to address this issue obliquely. It could be useful to collect the practice of non-state armed groups in order to bolster the argument that the customary norm enjoys universal acceptance. In this way engagement could include a discussion of practice by armed non-state actors which demonstrates the attachment to the norm in question. Having said this, it should be clear that contrary practice might be seen as a violation of the norm rather than eroding the case for its existence. Nor should such violations be seen as evidence which undermines the case that the norm exists in the first place. Despite the dangers of such an exercise the advantages would seem to outweigh the disadvantages. Some groups may be convinced of their ownership of some norms and therefore be more likely to respect those norms in turn leading to a better protection for civilians.

\footnotetext{
${ }^{180}$ See eg UN Doc. A/58/546-Corr.2S/2003/1053-Corr.2, 19 April 2004.
} 
2. Thought should be given to explicitly applying customary norms to armed nonstate actors without the need to first determine the existence of an armed conflict and 'recognizing' an armed non-state actor as a 'party' to that armed conflict. This has already started, as we saw, in the context of the work of the UN with regard to the protection of children in armed conflict where the mandate extends to 'other situations of concern'. Other UN Special Mechanisms are likely to have to report on armed groups operating outside the existence of an armed conflict. ${ }^{181}$ When international and nongovernmental organizations catalogue and monitor violations by non-state actors there may be room for an approach which explores how these norms apply irrespective of whether or not there is a recognized armed conflict. Many customary norms concerning, hostage-taking, recruitment of children, sexual violence are not dependent on the existence of an armed conflict.

\section{Universal Standards}

We have seen how a variety of monitoring mechanisms scrutinise the behaviour of armed nonstate actors with regard to universal standards. This occurs through references to human rights responsibilities monitored by the UN's special procedures and its field missions, and it is central to the emerging methodology of human rights non-governmental organizations.

1. The aborted work on 'The fundamental standards of humanity' might be usefully revisited. ${ }^{182}$ The issue has fallen off the agenda of the new Human Rights Council, but it is worth recalling the last sentence from the last report to the Human Rights Commission: 'The question of how to secure better compliance with fundamental standards of humanity by non-State actors also merits further attention. ${ }^{183}$ Today there is simply too much confusion over what constitutes the core standards that all groups must abide by due to the application of customary international law (including international criminal law) and what standards might be acceptable to such groups and which could therefore form the content for new commitments. In order to develop this new text is plain that one needs not only participations from such groups in the exercise, but also a participation which leads to meaningful and effective ownership. Such ownership should in turn bring about better protection of civilians.

\footnotetext{
${ }^{181}$ Consider the 'Statement by Professor Philip Alston, UN Special Rapporteur on extrajudicial executions Mission to Colombia 8-18 June 2009': 'FARC and ELN guerrillas continue to carry out significant numbers of unlawful killings, especially in order to control and instill fear in rural populations, to intimidate elected officials, to punish those alleged to be collaborating with the Government, or to promote criminal objectives. Their indiscriminate and inhumane use of landmines also kills and maims many.' Report forthcoming May 2010.

${ }^{182}$ See A. Eide, T. Meron, and A. Rosas, 'Combating Lawlessness in Gray Zone Conflicts Through Minimum Humanitarian Standards ', AJIL, vol. 89 (1995) 215-223; D. Petrasek, 'Moving Forward on the Development of Minimum Humanitarian Standards' 92 AJIL (1998), 557-563; J.-D. Vigny and C. Thompson, 'Fundamental Standards of Humanity: What Future?', vol. 20 Netherlands Quarterly of Human Rights (2002) 185-99; and the latest reports of the UN Secretary-General on 'Fundamental Standards of Humanity: E/CN.4/2006/87 of 3 March 2006 and A/HRC/8/14 of 3 June 2008. The issue was last discussed by the UN Commission of Human Rights (Decision 2004/118) and has never been reconsidered by the UN Human Rights Council.

${ }^{183}$ Report of the Secretary-General on 'Fundamental standards of humanity' E/CN.4/2006/87, 3 March 2006 at para. 31.
} 
2. A new text setting out specific obligations for non-state actors could avoid getting tangled up with the process of determining what is binding as customary international law for states. This could be done by stating from the outset that the principles were designed exclusively for armed non-state armed groups. In this way governments would not feel obliged to prevent the emergence of new norms that might be seen as applicable to state actors. Of course objections will be raised that this flies in the face of reciprocity in armed conflict and that such an exercise risks undermining existing customary obligations. But we have already seen that the obligations in an internal armed conflict will not always be perfectly symmetrical: the obligation to 'legally' constitute a court to try one's detainees cannot be seen as identical when applied to non-state actors, and indeed most scholars would admit that the scope of several international obligations will not be identical when applied to each side. Furthermore by setting out standards which go beyond customary international law one could detail those norms that are expected to be observed even outside the existence of an armed conflict as understood by international humanitarian law. In this way one could avoid forcing a government to admit that a group had reached a certain level of organization and control, and avoid having to prove that the violence had reached a certain intensity. The standards would apply all to the time and to all armed groups. Such 'fundamental standards of humanity to be respected by armed groups' could make a meaningful contribution to the protection of civilians. The key to their success will be the generation of a sense of ownership. 